\title{
Universiteit
}

Leiden

The Netherlands

\section{Reflections on the Mesolithic burial pits at Mariënberg (province of Overijssel), the Netherlands}

Louwe Kooijmans, L.P.; Niekus M.J.L.Th.

\section{Citation}

Louwe Kooijmans, L. P. (2012). Reflections on the Mesolithic burial pits at Mariënberg (province of Overijssel), the Netherlands. In A Mind Set on Flint. Studies in Honour of Dick Stapert (pp. 401-424). Groningen: Barkhuis, Groningen University Library. Retrieved from https://hdl.handle.net/1887/76582

Version: $\quad$ Not Applicable (or Unknown)

License: $\quad$ Leiden University Non-exclusive license

Downloaded from: $\quad$ https://hdl.handle.net/1887/76582

Note: To cite this publication please use the final published version (if applicable). 


\title{
26 Reflections on the Mesolithic burial pits at Mariënberg (province of Overijssel), the Netherlands
}

\author{
Leendert Louwe Kooijmans
}

\begin{abstract}
A group of extraordinary features, excavated at Mariënberg and interpreted as a small Late Mesolithic cemetery has been debated ever since their first publication. It is the combination of pit shapes, profuse red staining by ochre (?) and exceptional 'grave gifts' such as shaft polishers that has so far found no parallel anywhere in the Mesolithic record. This paper is intended to critically scrutinize all of the field data and related arguments. It comes to new views on quite a number of aspects of the features, especially their precise age, their relation to longterm domestic activities at the site, the formation processes of the red staining and the issue of the pit shapes. A new view on their European context is given in reference to the overviews of Mesolithic burial customs by Judith Grünberg. The final conclusion is that these features must indeed have been burial pits, particularly in the absence of any more convincing alternative explanation. The equally exceptional cemeteries of Téviec and Hoëdic in Brittany offer some distant parallels.
\end{abstract}

Keywords: Mesolithic, Netherlands, sitting graves, red ochre, shaft polishers.

\section{Introduction}

Between 1975 and 1980 an excavation was undertaken of an extensive Mesolithic activity area close to the village of Mariënberg, in the province of Overijssel (Fig. 1). The site was situated on a prominent coversand ridge along the southern bank of the Vecht river valley and characterised by a large number of (hearth-)pits.

The excavation was carried out by the farmers / owners of the land under supervision of the provincial archaeologist, Dr. A.D. Verlinde, with the help of field technician G. van Haaff. The top soil, consisting of a Plaggen soil cover and remains of an underlying podzol iron pan, were removed by a mechanical shovel. The top of the underlying coversand was subsequently shovelled clean by hand in a number of well-

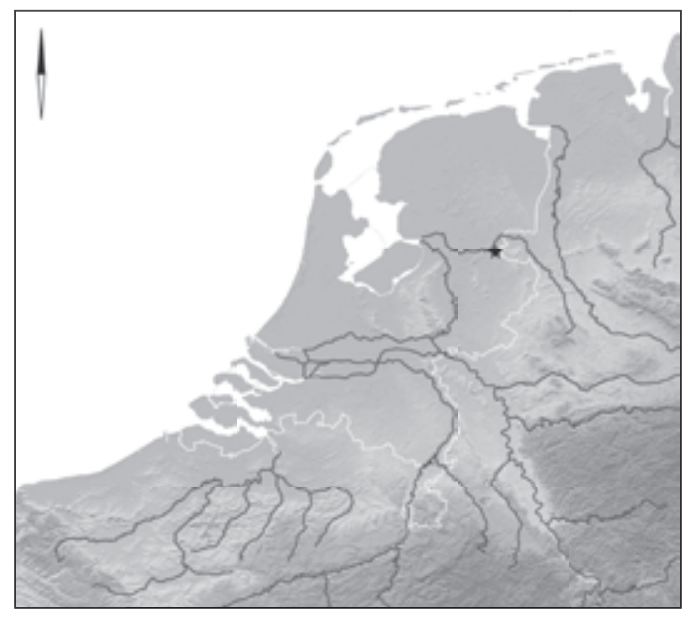

defined areas and all features mapped. At the centre of the excavation was the $20 \times 100 \mathrm{~m}$ 'Schaapskooi' area, named after the adjacent sheep pen, in which not only 292 of these pits have been documented, but also a remarkable cluster of six pit features, which as a group had no parallels in the Netherlands or elsewhere in Europe (Fig. 2) (Verlinde \& Newell, 2006).

The six pits were interpreted as Late Mesolithic graves of seated individuals but this has been met by scepticism from their discovery onward, although alternatives were not easily at hand. In order to resolve this issue this paper will carefully scrutinize the data, arguments and interpretation in order to either confirm the hypothesis or to develop alternative and better founded suggestions for the pits.

For this purpose all publications on the site have been carefully read, field drawings and colour slides have been consulted, the most important finds have been looked at and studied. Not included are the finds collected in the course of time from the surface and the Plaggen soil cover. I will first deal with the primary evidence, and then review the wider NW European context.

\section{Mesolithic activities}

It makes sense to first reflect on the (hearth-) pits, especially on their dating, since the presumed graves have been dated on the basis of their relation to these features. 


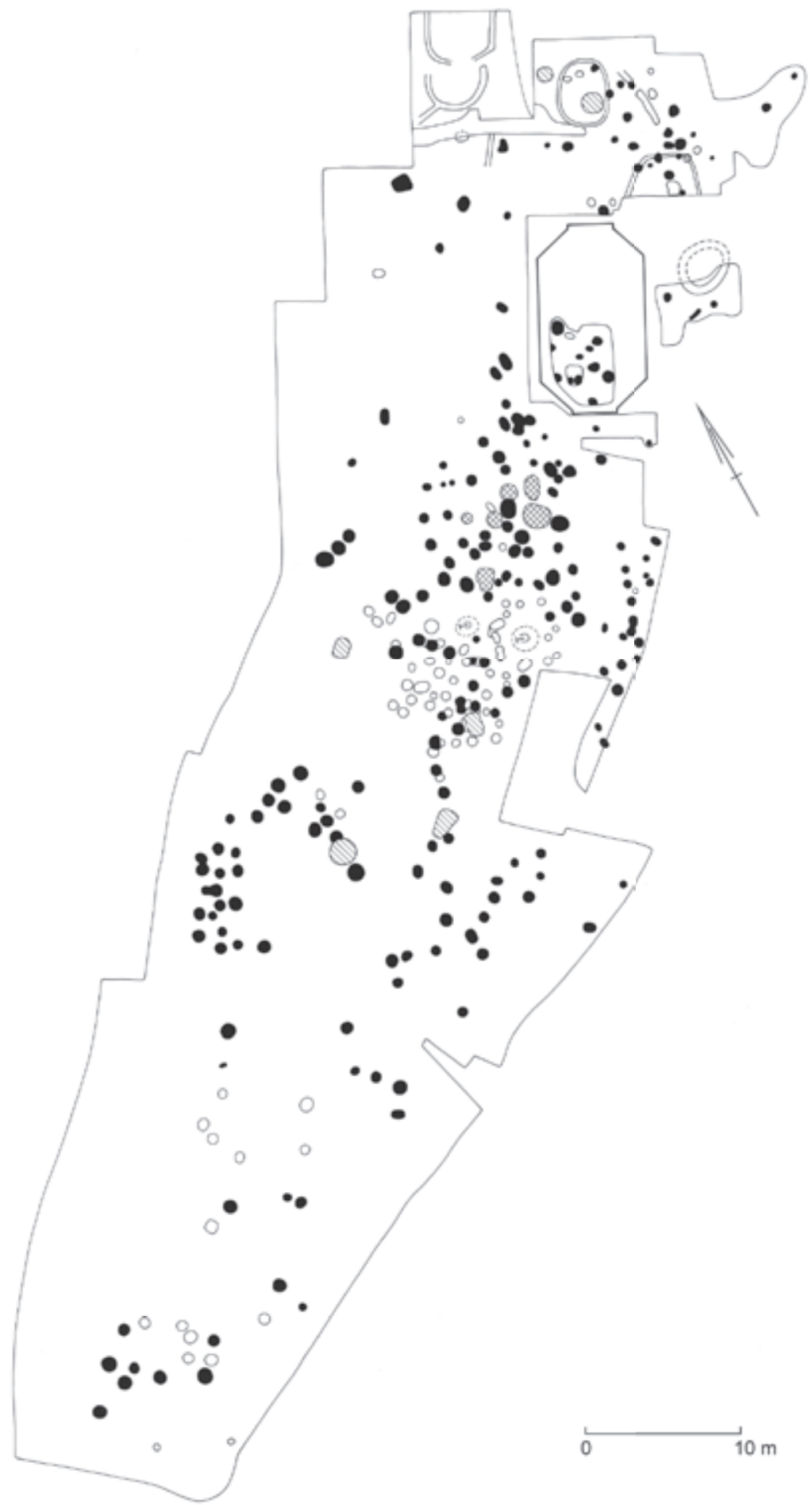

Figure 2. Mariënberg. Excavated Schaapskooi area with Mesolithic pits (white), hearths (black), and burial pits (cross hatched). Beaker flat graves hatched. Scale 1:500 (source Verlinde \& Newell, 2006).

This type of Mesolithic site, characterized by many hundreds of hearth-pits (Peeters \& Niekus, 2005), is known from a series of other locations in the northern part of the Netherlands, e.g. Nieuwe Pekela (Groenendijk,
1987, 2001), Zwolle (Hermsen, 2006), Hattemerbroek (Lohof et al., 2011) and Swifterbant-Bisonweg (Hamburg, pers. comm.). These sites are interpreted as special activity areas, i.e. sites for special processing outside the 


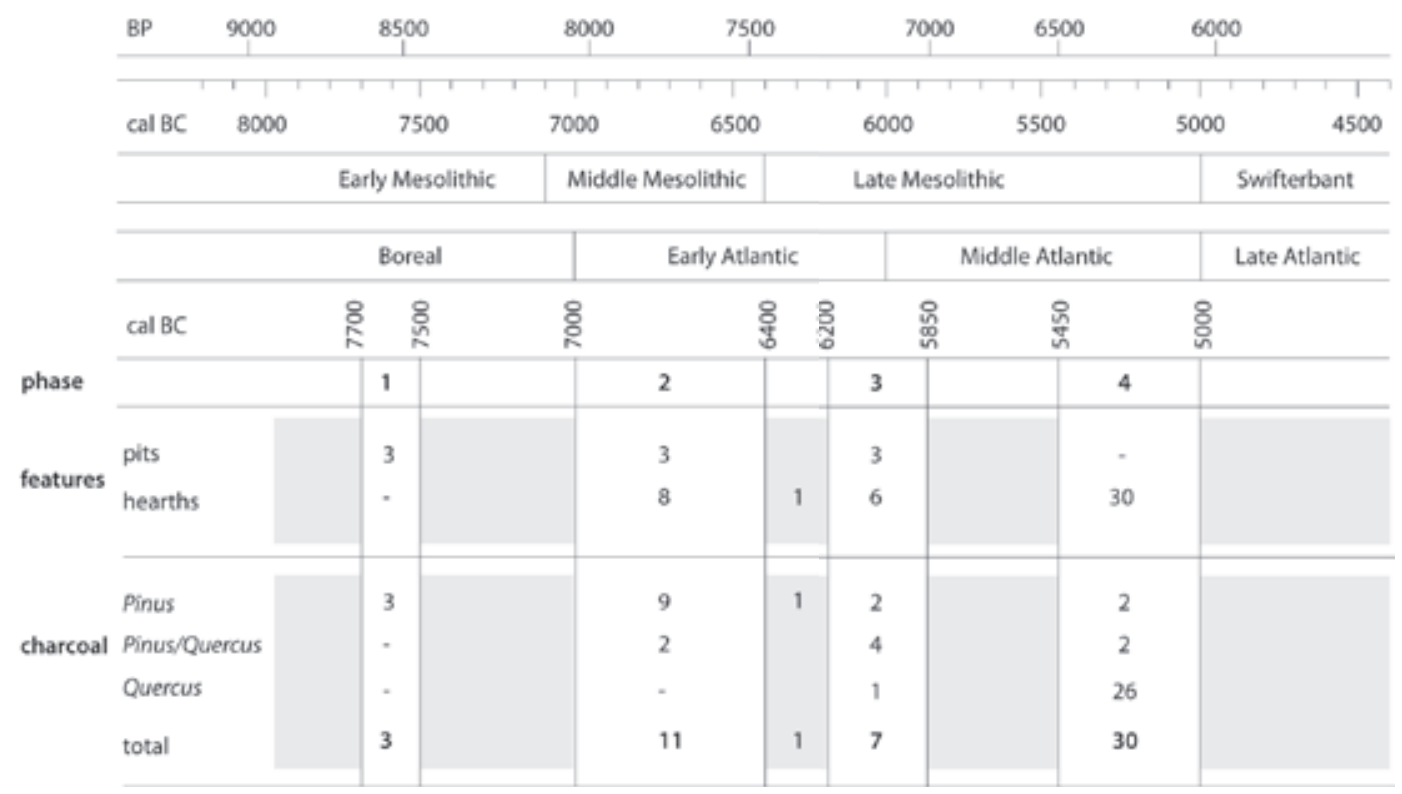

Figure 3. Mariënberg-Schaapskooi. Phasing of Mesolithic pits and hearths, based on $52{ }^{14} \mathrm{C}$ dated features with charcoal identification spectra. Incidental identifications of other species than Pinus and Quercus ignored. Data from Verlinde \& Newell, 2006: 100 and Niekus, 2006: 88-89. Phase boundaries - especially the lower limit of phase 2 - should be seen as rather diffuse as a consequence of the wide range of the calibrated standard deviations of the individual dates. N.B. the additional series produced one date in the phase $2 / 3$ hiatus, as distinguished in the excavation report (graph J. Porck).

domestic 'camp locations', which may explain the very poor flint industry found at Mariënberg (Groenendijk, 1987; Groenendijk \& Smit, 1990). It has recently been suggested on the basis of chemical analysis of charred remains that pits at the Hattemerbroek site had been used for the production of tar or bitumen (Kubiak-Martens et al., 2008).

The Mariënberg pits have been separated into those with hearths $(n=213)$, coloured black by dispersed charcoal, and those pits $(n=79)$ generally lacking charcoal, and coloured (light) grey. Both groups of pits had homogenous coloured fills, without any microstratigraphy or differentiation. Sections of the Hattemerbroek hearth-pits (Lohof et al., 2011: Fig. 4.1) show that these were only the basal remnants of features; any colouring of the shaft fills had disappeared and the charcoal layer at the base had been transformed into a diffuse mass as a result of bioturbation, and similar in detail to the 'ochre layers' in the Mariënberg graves. ${ }^{2}$

The finds in the pit features could not help specify a date better than Mesolithic, because of the modest quality and restricted quantity of the material found. Two thirds of the pits produced no artefacts at all, the others only small amounts, indicating a general paucity of Mesolithic waste at the surface, which confirms that the site should better be interpreted as a special activity area rather than a base camp.
A total of $60{ }^{14} \mathrm{C}$ dates on charcoal from pits and hearths is available for the Mariënberg site, 57 of which from the Schaapskooi area. They have been made in two runs: one of 44 by the excavating institute and published in the final report, an additional 16 on behalf of a Mesolithic dating project, published by Niekus (2006). On five occasions the Pinus and Quercus fraction of one hearth feature have been dated separately. The fractions showed no or only modest age differences, which would argue firmly against any contamination. So altogether 52 features have been dated in the Schaapskooi area: nine (light coloured) pits and 43 (black) hearths.

In all, the activities appear to cover the period between 7600 and $5000 \mathrm{cal} \mathrm{BC}$, of the Middle and Late Mesolithic. Four phases can be identified, separated by three major hiatuses in the ${ }^{14} \mathrm{C}$ series (Fig. 3; Verlinde \& Newell, 2006: Fig. 14 \& Table 2). ${ }^{3}$ Phase 1 has exclusively light features, phase 4 exclusively hearths. In the intermediate phases both categories occur side by side. This gradual replacement of 'ordinary' pits by those rich in charcoal may indicate a shift in the processing either of the specific activity itself, or of the way a specific process was performed. The charcoal of all ${ }^{14} \mathrm{C}$ samples has been identified to species. It mainly appears to be pine and oak: in phase 1 exclusively pine, then - after a 500 year hiatus in the Late Boreal - pine is still dominant in the Early Atlantic 
Table 1. Mariënberg-Schaapkooi, burial pits, basic data. ${ }^{1} \mathrm{p}=$ polisher, $\mathrm{h}=$ hammerstone, $\mathrm{n}=$ flint, ${ }^{2} 25 \mathrm{~cm}$ added to depth.

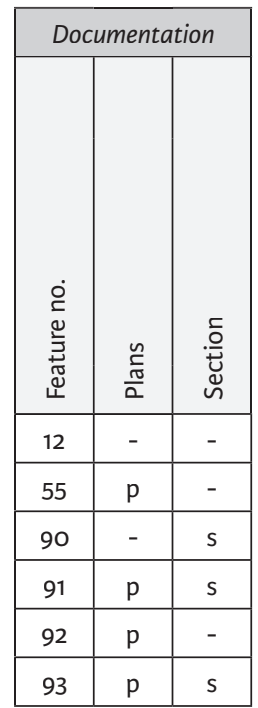

\begin{tabular}{|c|c|c|c|c|c|}
\hline \multicolumn{6}{|c|}{ As published } \\
\hline \multicolumn{2}{|c|}{ shaft } & \multicolumn{3}{|c|}{ red-stained sand } & $\begin{array}{l}\text { deposited } \\
\text { artefacts' }^{1}\end{array}$ \\
\hline 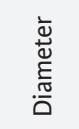 & 言 & $\frac{\stackrel{0}{\Xi}}{\frac{\Xi}{\circ}}$ & 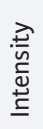 & 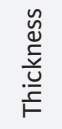 & \\
\hline $\mathrm{cm}$ & $\mathrm{cm}$ & litres & & $\mathrm{cm}$ & \\
\hline 80 & 130 & 151 & + & (30) & ppp $\mathrm{h}+5$ \\
\hline 90-110 & 90 & 191 & + & 30 & 3 \\
\hline 55 & 45 & 30 & . & 20 & - \\
\hline 140 & 135 & 235 & + & 35 & 7 \\
\hline 80 & 50 & 44 & . & (35) & $\mathrm{h}+7$ \\
\hline 100 & 80 & 159 & + & 30 & ppp hh +17 \\
\hline
\end{tabular}

\begin{tabular}{|c|c|c|c|}
\hline \multicolumn{4}{|c|}{ Proposed } \\
\hline \multicolumn{4}{|c|}{ shaft } \\
\hline 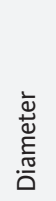 & $\begin{array}{l}\text { 容 } \\
\text { Q }\end{array}$ & 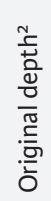 & 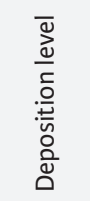 \\
\hline $\mathrm{cm}$ & $\mathrm{cm}$ & $\mathrm{cm}$ & m NAP \\
\hline 80 & 125 & 150 & c. 8.00 \\
\hline 80 & 70 & 95 & 8.70 \\
\hline 55 & 45 & 70 & - \\
\hline 120 & 90 & 115 & 8.57 \\
\hline 80 & 42 & 67 & 8.84 \\
\hline 90 & 30 & 55 & 8.94 \\
\hline
\end{tabular}

Table 2. Mariënberg-Schaapkooi, identification of charcoal from the fills of burial pits and from hearth 15. Data from Verlinde \& Newell, 2006: Appendix 3 (BIAX) and 132 (others).

\begin{tabular}{|c|c|c|}
\hline & $\begin{array}{c}\text { Feature \& } \\
\text { sample no. }\end{array}$ & Lab. \\
\hline \multirow{8}{*}{$\frac{\frac{n}{\frac{n}{2}}}{\frac{\pi}{\frac{\pi}{5}}}$} & 12 & others \\
\hline & 55 & BIAX \\
\hline & 91 & BIAX \\
\hline & $92-1$ & BIAX \\
\hline & $92-2$ & BIAX \\
\hline & $92-3$ & BIAX \\
\hline & 93 & others \\
\hline & $93-2$ & BIAX \\
\hline
\end{tabular}

\begin{tabular}{|r|r|r|r|r|}
\hline Pinus & cf. Pinus & Quercus & Betula & indet. \\
\hline+ & - & + & - & - \\
\hline 33 & - & 1 & - & - \\
\hline 4 & - & 8 & - & 7 \\
\hline 20 & - & - & - & - \\
\hline 20 & 9 & - & - & - \\
\hline 9 & - & - & - & 15 \\
\hline 12 & - & 2 & 1 & - \\
\hline 25 & - & - & - & - \\
\hline
\end{tabular}

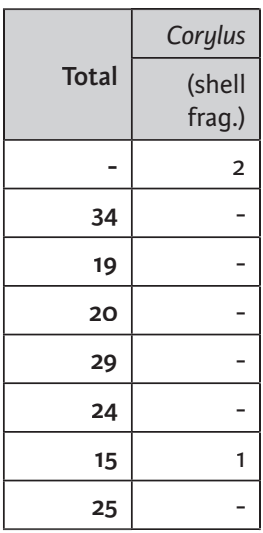

\begin{tabular}{|l|l|l|}
\hline & & Total \\
\hline Hearth & 15 & others \\
\hline
\end{tabular}

\begin{tabular}{|r|r|}
\hline 123 & 9 \\
\hline- & \\
\hline
\end{tabular}

\begin{tabular}{|l|l|l|}
\hline Rejected & 92 & others \\
\hline
\end{tabular}

19

19

\begin{tabular}{|r|r|r|r|}
\hline 9 & 11 & 1 & 22 \\
\hline- & 823 & - & - \\
\hline
\end{tabular}

\begin{tabular}{|l|l|}
\hline 166 & - \\
\hline 823 & - \\
\hline
\end{tabular}

(phase 2), only to be fully replaced in the course of the Middle Atlantic (phase 4), by exclusively oak. Pure Pinus samples have nonetheless been dated as late as $5500 \mathrm{cal} \mathrm{BC}$ at this site. This internal chronological system is of importance for more precisely dating the burial pits.

For a functional interpretation we should realize that the site was used with some major and possibly also some minor interruptions over a period of about 2.5 millennia. So the site may not have been visited each year and only one pit or hearth may have functioned at a time: the extensive spread of features could therefore mainly reflect duration and not intensity of use. It is typically the palimpsest of a persistent place in the long-term activity spectrum of a small local group within a long tradition ( $c f$. Amkreutz, in prep.). The activities must have been very restricted at any specific time.

\section{A Mesolithic cemetery?}

The 'Mesolithic cemetery' comprises six cylindrical to slightly conical pits, lying close together in a cluster measuring only $5 \times 8 \mathrm{~m}$; the absence of any human remains is not 


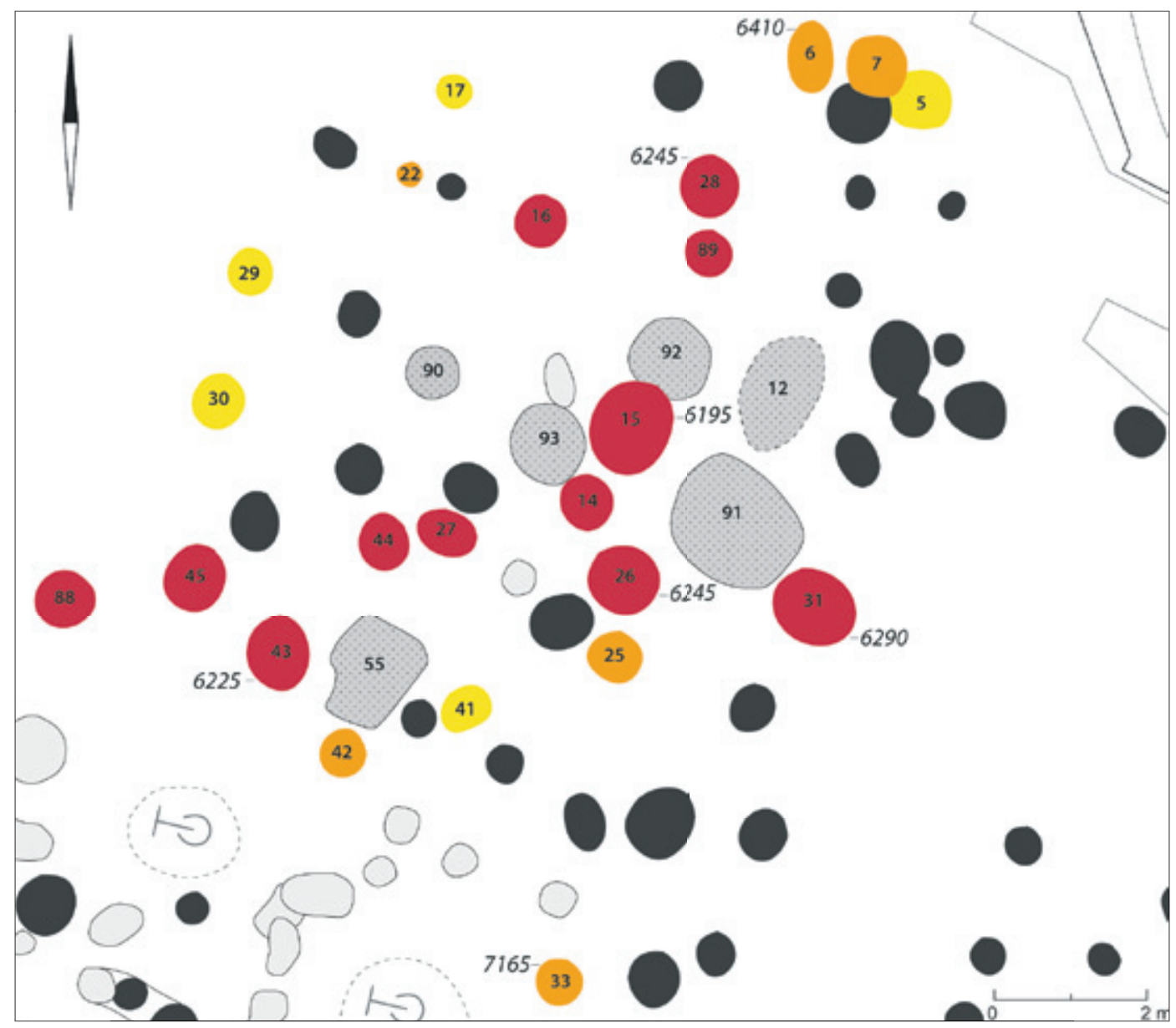

Figure 4. Mariënberg-Schaapskooi, field plan, detail. Mesolithic burial pits in dotted grey. Yellow: Pinus hearths, red: Quercus hearths, orange: Pinus/Quercus combined. ${ }^{14} \mathrm{C}$ dates BP without standard deviation in italics. Black: hearths without charcoal spectra or ${ }^{14} \mathrm{C}$ dates. Scale 1:100. For the data see Table 3 (map J. Porck).

unexpected and can easily be explained by the acid soil conditions. ${ }^{4}$ The most remarkable feature of the pits is the conspicuous bright red deposit in their lower fills, not seen before anywhere in the Lower Rhine Area, and indicated as 'ochre layer'. A second significant aspect is the presence of two sets of three 'shaft polishers' in two of the pits plus a series of relatively large flint blades (Verlinde, 1979, 1982; Van Es et al., 1988: 132-134; Verlinde, 2005; Verlinde \& Newell, 2005, 2006).

\section{Documentation}

The six features have been documented in different ways and not all in equal detail (Table 1). No. 12 was discovered more or less by accident and its cross-section schematically reconstructed based on oral information. The feature stands out due to its original depth of c. $140 \mathrm{~cm}$ and a relatively rich find assemblage. Nos. 55 and 92 have been excavated in seven horizontal spits of $10 \mathrm{~cm}$, all levels were drawn to 1:20 scale, allowing the reconstruction of a section through the pit. For nos. 91 and 93 a more sophisticated method was used: one half was excavated in levels first, followed by a field drawing of the cross-section and the excavation of the other half. Lastly, a small feature, no. 90, was found during the final, mechanical testing of the area and as a consequence was damaged by the mechanical digger. Only the section of its bottom half has been documented.

The careful and detailed field plans and sections made by field technician Gerard van Haaff together with the colour photos of the nos. 55, 91 and 92 have been of great help in the reassessment. The published plans and sections give a rather crude and schematic view of reality ( $c f$. Fig. 5 a with Verlinde \& Newell, 2006: Fig. 78A). Nevertheless, four of the features offer us detailed information, while the other two (nos. 12 \& 90) must be viewed as additional evidence. 

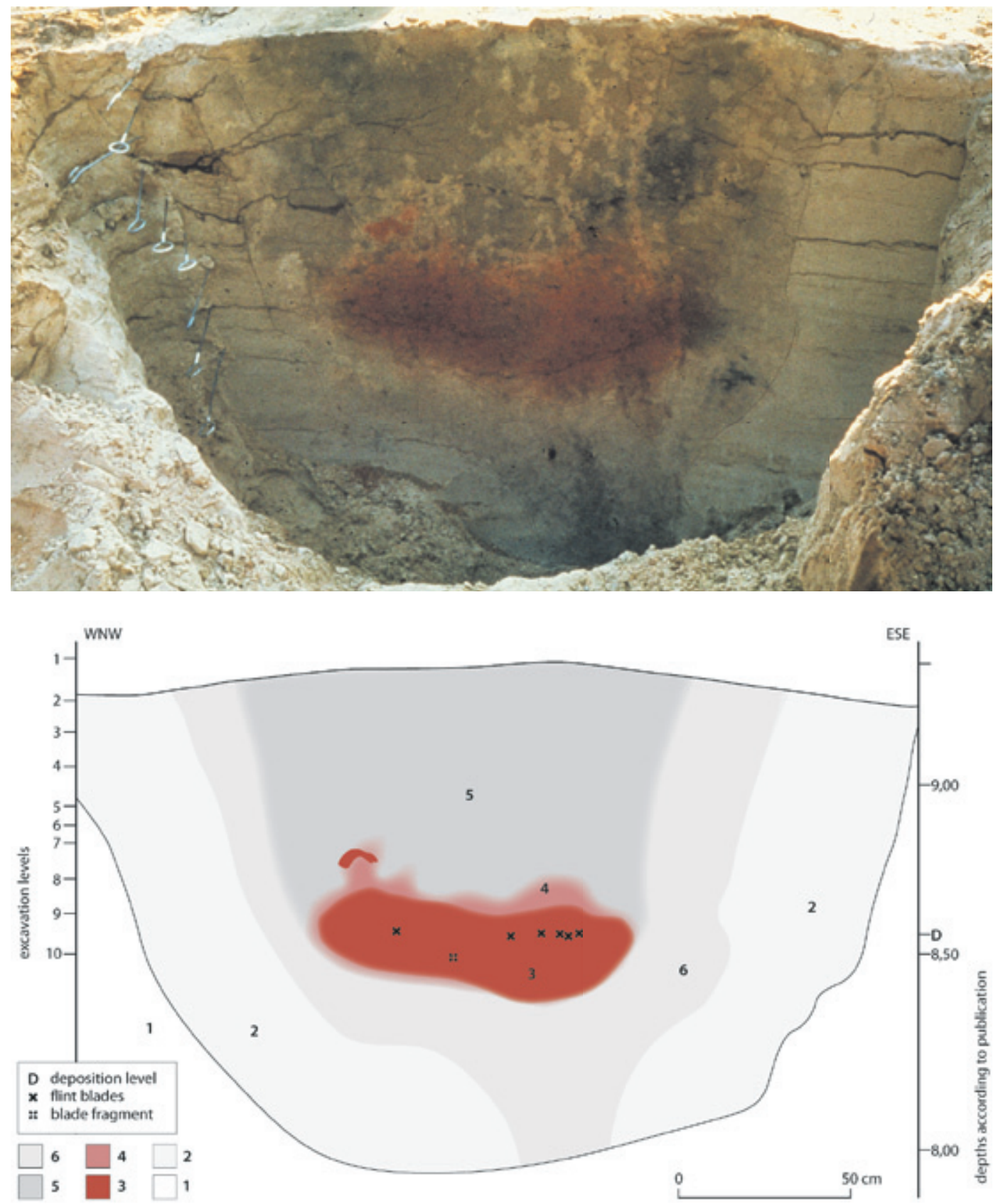

Figure 5. Mariënberg-Schaapskooi, section of burial pit no. 91. Field photograph (a) and interpretation as proposed in this paper (b). Key to Figure 5b: 1. not excavated, 2. coversand, 3. red-stained sand, 4. red-stained sand, diffuse margin, 5. pit fill, 6. coversand affected by soil processes (photo State Service for Archaeological Research, now State Service for the Cultural Heritage or RCE and drawing J. Porck).

\section{Dating}

It was not possible to date the burial pits directly by ${ }^{14} \mathrm{C}$ or artefact typology. The fact that the burial pits were situated within a dense cluster of hearth-pits without any cross-cutting was used as an argument for synchronism: earlier pits would still have been visible when later pits were dug. This would imply a date of around 5200 cal BC, as argued above. Some objections can however be made. First there is in fact one intersecting cut: that of large hearth no. 15 over grave 92, well indicated on the field drawing, but less apparent on the published overview maps. ${ }^{5}$ The relatively restricted intersection was disputed in the field, considered to be a secondary phenomenon resulting from caving in of the pit's walls and as a result ignored in the published report. We should however realize 


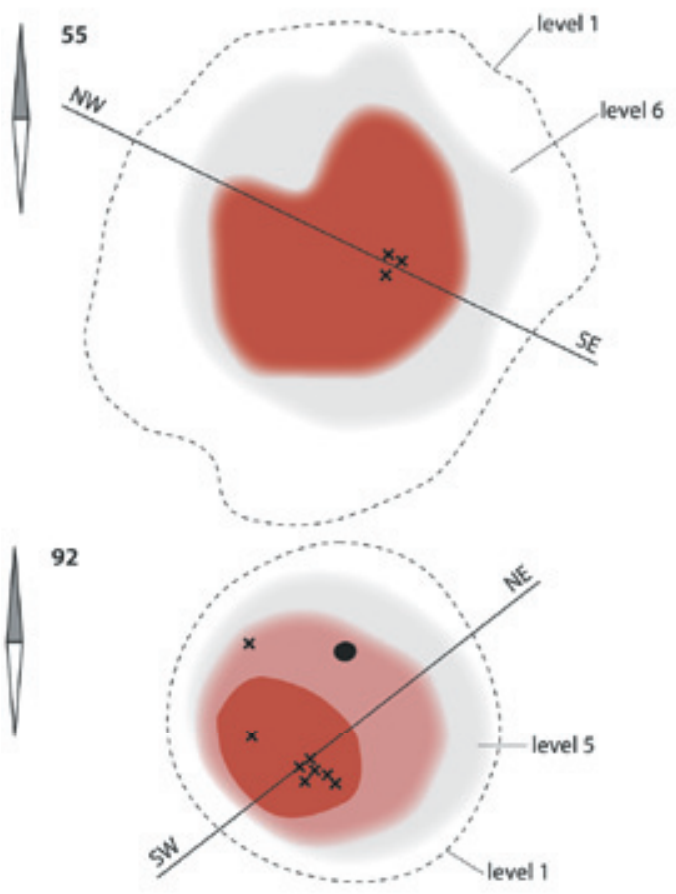

NW

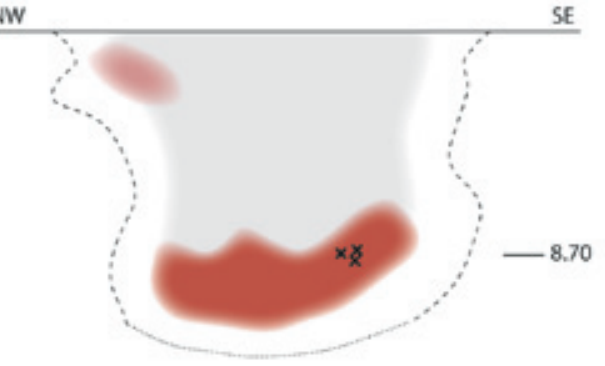

SW NE
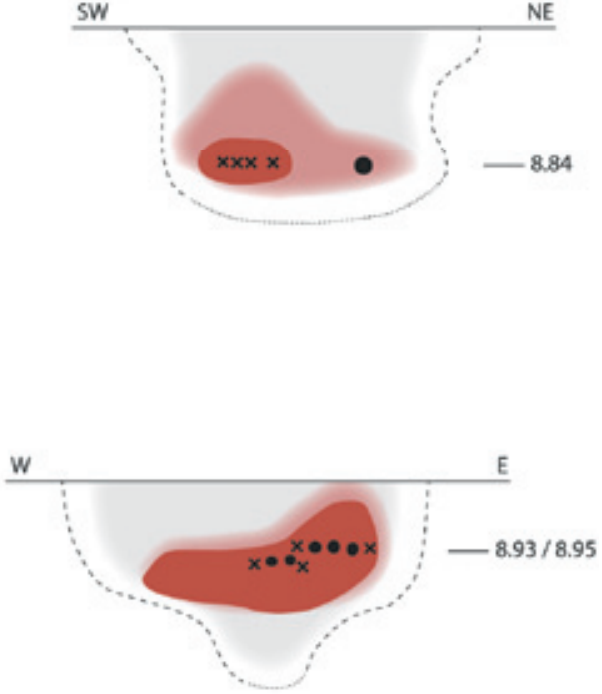

93

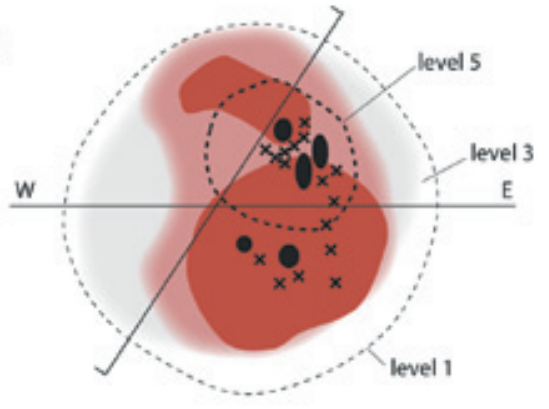

91
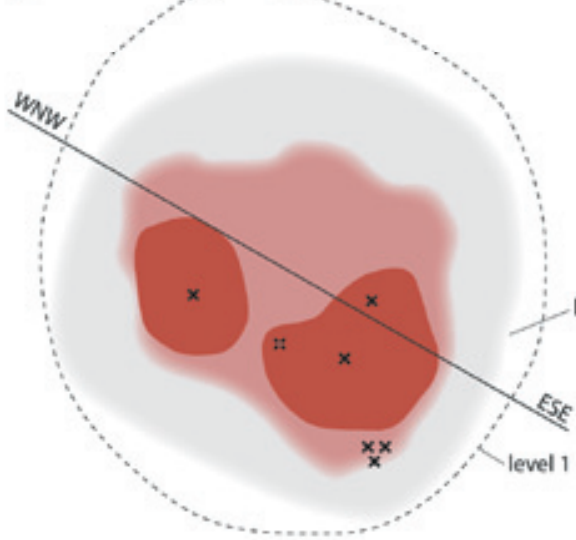

WNVI

ESE

Figure 6. Mariënberg-Schaapskooi, plans and sections of burial pits 55, 91, 92 and 93. Plans redrawn after the original field plans. New sections of nos. 55, 92 and 93 constructed on the basis of the documented levels. Section of no. 91 is a generalisation of Figure 5. Finds in deposition levels have been projected onto sections. Scale 1:25 (drawings ). Porck). 
Table 3. Mariënberg-Schaapkooi, identification of charcoal from hearth-pits in the direct surroundings of the burial pits (see Fig. 4). Data from Verlinde \& Newell, 2006: quantitative data after Appendix 3 (BIAX identifications); qualitative data after 144-147 (earlier identifications). Key: $\mathrm{Ac}=$ Acer, $\mathrm{Al}=$ Alnus, $\mathrm{Co}=$ Corylus, $\mathrm{Fr}=$ Fraxinus, $\mathrm{P}=$ Pinus, $\mathrm{Po}=$ Pomoidea, $\mathrm{Pr}=$ Prunus, $\mathrm{Q}=$ Quercus, $\mathrm{Sa}=$ Salix.

\begin{tabular}{|c|c|c|}
\hline \multirow[b]{2}{*}{$\begin{array}{c}\text { Hearth } \\
\text { no. }\end{array}$} & \multicolumn{2}{|c|}{${ }^{14} \mathrm{C}$ dates } \\
\hline & calBC & BP \\
\hline 5 & & \\
\hline 17 & & \\
\hline 29 & & \\
\hline 30 & & \\
\hline 41 & & \\
\hline
\end{tabular}

\begin{tabular}{|r|r|r|r|r|}
\hline \multicolumn{5}{|c|}{ charcoal identification } \\
\hline $\mathrm{P} \&$ cf. $\mathrm{P}$ & Q \& cf. Q & $\mathrm{Al}$ & $\mathrm{Fr}$ & Var. \\
\hline 5 & - & - & - & indet \\
\hline 67 & - & - & - & - \\
\hline 5 & - & - & - & - \\
\hline $\mathrm{P}$ & - & - & - & - \\
\hline 22 & - & - & - & - \\
\hline
\end{tabular}

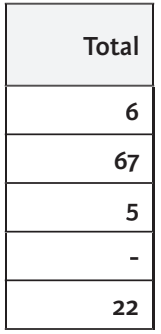

\begin{tabular}{|c|c|c|}
\hline 6 & $5400-5300$ & 6410 \\
\hline 7 & & \\
\hline 22 & & \\
\hline 25 & & \\
\hline 33 & c. 6000 & 7165 \\
\hline 42 & & \\
\hline
\end{tabular}

\begin{tabular}{|r|r|r|r|r|}
\hline 8 & 221 & 2 & 3 & Sa \\
\hline 1 & 1 & 8 & - & - \\
\hline+ & + & - & - & Po \\
\hline+ & + & - & - & - \\
\hline+ & + & - & - & $\mathrm{Ac}$ \\
\hline 3 & 51 & - & - & $\mathrm{Pr}$ \\
\hline
\end{tabular}

\begin{tabular}{|r|}
\hline 234 \\
\hline 10 \\
\hline- \\
\hline- \\
\hline- \\
\hline 54 \\
\hline
\end{tabular}

\begin{tabular}{|l|l|l|}
\hline 14 & & \\
\hline 15 & $5200-5100$ & 6195 \\
\hline 16 & & \\
\hline 26 & $5250-5100$ & 6245 \\
\hline 27 & & \\
\hline 28 & $5250-5100$ & 6245 \\
\hline 31 & $5300-5200$ & 6290 \\
\hline 43 & $5200-5100$ & 6225 \\
\hline 44 & & \\
\hline 45 & & \\
\hline 88 & & \\
\hline 89 & & \\
\hline
\end{tabular}

\begin{tabular}{|r|r|r|r|r|}
\hline- & + & - & - & - \\
\hline- & 823 & - & - & - \\
\hline- & + & - & - & - \\
\hline- & 14 & 24 & 1 & Co \\
\hline- & 101 & - & - & - \\
\hline- & + & - & - & - \\
\hline- & + & + & - & - \\
\hline- & 160 & - & - & - \\
\hline- & 113 & - & - & - \\
\hline- & 40 & - & - & - \\
\hline- & + & - & - & - \\
\hline- & + & - & - & - \\
\hline
\end{tabular}

\begin{tabular}{|r|}
\hline- \\
\hline 823 \\
\hline- \\
\hline 41 \\
\hline 101 \\
\hline- \\
\hline- \\
\hline 160 \\
\hline 113 \\
\hline 40 \\
\hline- \\
\hline- \\
\hline
\end{tabular}

that the intersection at the former Mesolithic surface - at least $25 \mathrm{~cm}$ above the excavation level - will have been more distinct in view of the widening upward of both pits. So the ${ }^{14} \mathrm{C}$ date of feature 15 of $6195 \pm 35 \mathrm{BP}(\mathrm{GrN}-9951)$ gives us only a terminus ante quem for the burial pit and as such for the cluster as a whole.

From the upper fills of five burial pits in total eight charcoal samples have been identified to species (Table 2). ${ }^{6,7}$ All spectra are very consistent in showing an absolute dominance of Pinus, with the exception of one sample from burial pit 92. The deviant sample - showing an equal proportion of Pinus and Quercus - has to be rejected since all four samples from feature 92 should represent the same secondary charcoal washed in from the surrounding surface and so should show comparable proportions of species. There may have been an administrative error in the presentation of data. ${ }^{8}$

Within a circle with a diameter of c. $15 \mathrm{~m}$ around the burial pit cluster 48 hearth-pits have been mapped. Charcoal has been identified from 23 of these, of which five produced Pinus only, 12 Quercus only, and six a mixture of both (Table 3). Seven pits have been dated: five 'Quercus hearths' all late in phase 4, two 'mixed hearths' early in phase 4 and in phase 3. The all-Quercus hearths and late dates indeed show a striking spatial overlap with the burial pits, as already observed in the publication (Fig. 4). This is however considered to be coincidence in view of the total data set.

The Pinus charcoal, trapped in the grave fills, should relate to the older hearths, situated at a 
slightly greater distance. This charcoal is - like the Mesolithic settlement waste in the same fills - considered to be secondary and to be derived from the surrounding surface. It shows that at the time the pits were dug, predominantly Pinus charcoal was lying around. As such the spectra of phase 2 ('mode III') give us a terminus post quem for the digging of the burial pits. The quasi absence of Quercus is an argument in favour of a date well before the local phase 4 ('mode I'). This altogether results in a date between phases 2 and 4 (cf. Fig. 3), in other words: either in phase 3 or in one of the hiatuses $2 / 3$ and $3 / 4$, roughly around $6000 \mathrm{cal} \mathrm{BC}$. Hearths dated to phase 3 had no distinct spatial relations with the grave cluster, which would mean burial outside areas of domestic activity. According to the hiatus option use was made of a former special activity site. Both are more satisfying interpretations on human behaviour, in our view, than burial in between hearth-pits that were in active use.

\section{The pit's shapes and fills}

The sections of the burial pits confront us with some interpretational problems in our understanding of the soil discolourations visible. How can a distinct volume of red-stained sand half-way down a seemingly unstratified fill be understood? What does the difference between the upper ('funnel') part and the lower fill imply? Why is the section outline so irregular, with locally even some undercutting in the rather loose sand? The clue lies in taphonomy, in the formation processes over a period of 8000 years.

I am well aware of the dangers of a reassessment of earlier field interpretations, but in this case such an approach is facilitated by a very clear photograph of the section of the well-documented feature no. 91 (Fig. 5a). The discolouration left by the original pit appears not easy to delineate sharply, and so the sharp lines, first those in the soil as a drawing aid and subsequently those of the drawing, must be considered as a bit misleading. The preserved pattern is in fact a vague relic or a 'ghost' of the original soil disturbance, diffused by soil processes, especially percolation, oxidation and bioturbation, in several phases through time. The pit content itself has been dissolved and oxidized, leaving only a vague differentiation in hues of grey of what originally will have been distinct differences. Fill material will also have been mixed by the same processes with the directly adjacent coversand, into which the pit was dug, resulting in a slightly 'dirty' transitional zone. This also applies to the bleaching of the shaft fills. Accepting these processes and their outcome would be in line with the suggested bioturbation in the hearthpits mentioned above.

The section of burial pit no. 91 has therefore been reinterpreted according to the taphonomic view outlined here (Fig. 5b). The constructed sections of the other burial pits have been based on this formation model (Fig. 6).

In the publication by Verlinde and Newell four elements have been distinguished in the sections: a funnel-shape at the top, then a cylindrical shaft, with an 'ochre layer' at its base, and at last an irregular shaped bottom, indicated as 'foot well', in line with the interpretation of the features as burial pits.

A 'funnel' was observed in four cases. We however interpret the most prominent example of a 'funnel' (the 'reconstructed' top part of feature 12) as a Late Neolithic flat grave in view of its shape and dimensions, its sharp transition to the shaft, and the long flint blade found at its base. The blade is comparable but larger than that in the Late Neolithic grave no. 670 at the same site. The remaining three funnels are not very impressive, but merely a slight and gradual widening of the upper part of the cylindrical or slightly conical shaft. I would suggest that a gradual widening is not a primary aspect, but may be the result of weathering - especially the caving in - of the pit's rim, indicating that the pit was only partially filled. A depression may have developed as result of compaction of the fill and by decay of the contained body, and / or the pit may not have been fully filled up. In each case this will have been followed by natural infilling processes. This would have left its location visible for some time, which helps to understand their clustering without intersections.

The fills of the shafts are described in contrast as "flecked (greenish) grey and dirty yellow", with vertical traces of later bioturbation. The grey component is interpreted as reflecting the humic content of the original brown forest soil, the yellow component as related to the yellow coversand, where the pit was dug into. 
Table 4. Mariënberg-Schaapskooi, composition of Mesolithic settlement waste in the red-stained units and upper fills of the burial pits, and in the site assemblage, finds from burial pits excluded. Data from Verlinde \& Newell, 2006: 125-130.

\begin{tabular}{|l|r|r|r|}
\cline { 2 - 4 } \multicolumn{1}{c|}{} & \multicolumn{3}{c|}{ No. } \\
\cline { 2 - 4 } \multicolumn{1}{c|}{} & Red-stained & Upper fill & Site \\
\hline Retouched artefacts & 2 & 11 & 127 \\
\hline Blades \& fragments & 10 & 30 & 322 \\
\hline Flakes \& fragments & 27 & 116 & 3,035 \\
\hline Cores / blocks & 7 & 14 & 664 \\
\hline Divers & 1 & 1 & 81 \\
\hline Total & 47 & 172 & 4,229 \\
\hline
\end{tabular}

\begin{tabular}{|r|r|r|}
\hline \multicolumn{3}{|c|}{$\%$} \\
\hline Red-stained & Upper fill & Site \\
\hline 4 & 6 & 3 \\
\hline 21 & 17 & 8 \\
\hline 57 & 67 & 72 \\
\hline 15 & 8 & 16 \\
\hline 2 & 1 & 2 \\
\hline 100 & 100 & 100 \\
\hline
\end{tabular}

The quasi-vertical walls of the shaft and the patchy appearance of its fill are indications that the pit was not left open and filled by natural processes, but indeed deliberately filled in with the excavated material, as already inferred by the excavators ( $c f$. Verlinde, 2005: 180). So lumps of the humic topsoil and yellow sand became mixed up. This contrast was faded by later soil formation processes, but had not fully disappeared. It is assumed that the extent of the red staining at the base of the fills approximately reflect the original diameter of the shafts and that the vague transitions between fill and the surrounding sand has been caused by later soil processes, as argued above, resulting in slightly narrower shaft diameters than originally published.

Most conspicuous in all fills is a thick unit of red-stained sand at the base of all pits or above it. It measured $20-35 \mathrm{~cm}$ and had volumes of 30-235 litres (Table 1). The units differ not only considerably in volume, but also in intensity: modest and faint in no. 92, massive and intense in nos. 91 and 93, 55 being intermediate (Table 1). These red coloured units have always been considered to result in some way from the deposition of red ochre (or natural red sand) at the base of the pits. The presence of ochre could however not be attested in spite of chemical and X-ray analysis. Three tiny pieces mentioned in secondary position in grave 92 (Verlinde \& Newell, 2006: 129) appeared to be concretions. The colour appeared to be caused by a thin skin of iron oxide $\left(\mathrm{Fe}_{2} \mathrm{O}_{3}\right)$ on the sand grains, which could easily be rubbed off. As such and visually it could not be distinguished from natural so-called red sand ( $c f$. below). Two possible explanations have been put forward:
1) The collection and deposition of natural red sand from an (unknown) location in the surroundings.

2) The mixing of sand with powder made from a mineral iron oxide - local iron ore, limonite or haematite.

In the first case the iron oxide would have been precipitated under natural conditions outside the features, implying that all sand would have been brought in. In the other case the powder would have been dissolved and the iron oxide precipitated secondarily in the features. It appears to be impossible to make a choice between either of these options. The first option would imply natural occurrences in the region at that time, in view of the quantities used. However, at present no others are known in the Vecht region in spite of large scale digging operations. If present in prehistory it will rarely have been visible in the undisturbed and grown over landscape, being a subsurface phenomenon (Bakker, 1991; Bakker \& Rogaar, 1993). ${ }^{9}$ The second option is met with scepticism from soil scientists. However a first counter argument against their view is that not only the sand had been stained red, but all flint artefacts as well and especially the shaft polishers (Fig. 7). A second argument against the 'red sand quarrying' option is the fact that the red-stained layers in the burial pits contained Mesolithic settlement waste, similar to the shafts and not fundamentally different from that of the site as a whole (Table 4).$^{10}$ This is in line with the idea of a transformation of the shaft fills and not with that of a separate and special deposit. The overrepresentation of (small) blades in the fills results from the very careful way these have been excavated, 


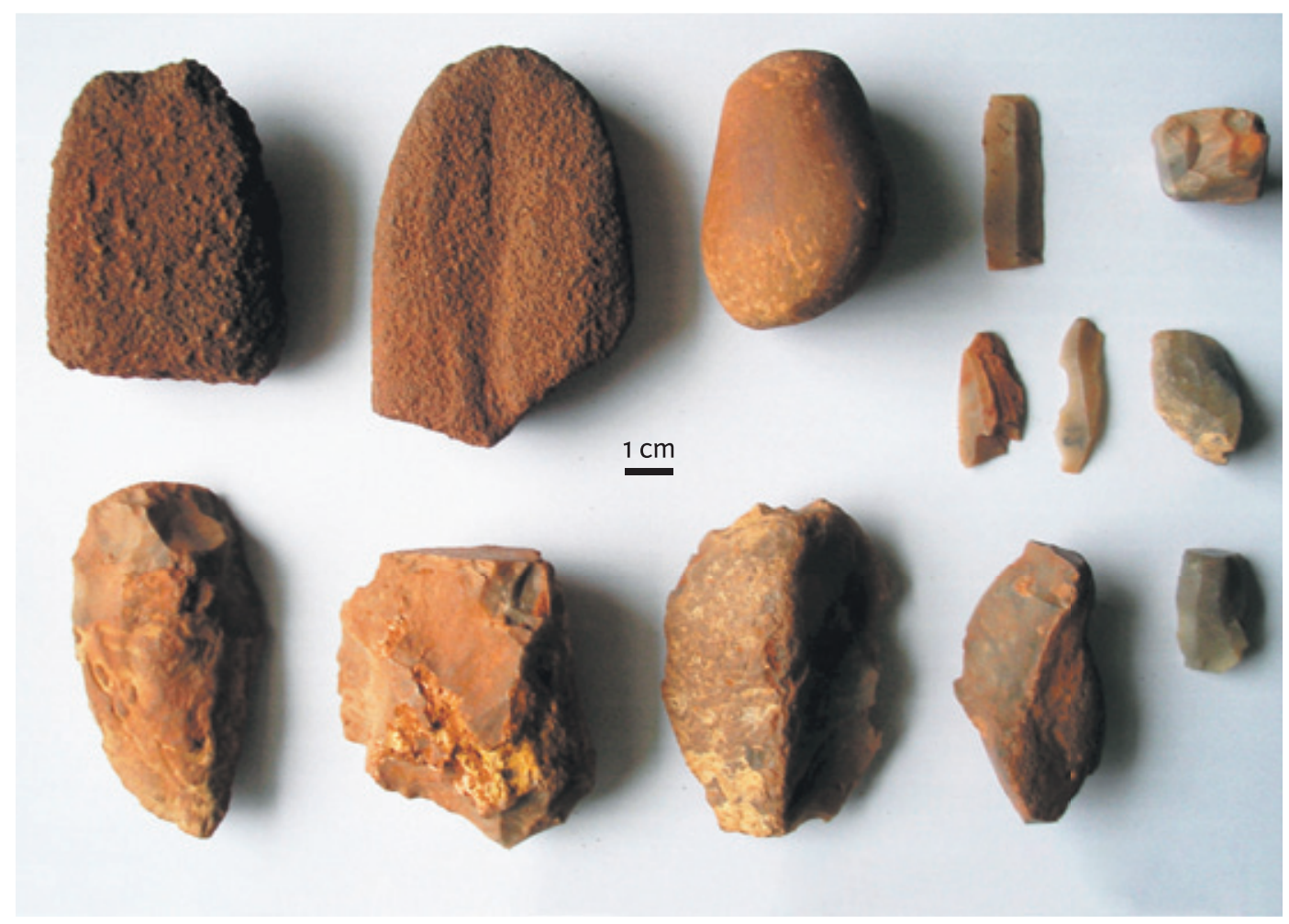

Figure 7. Mariënberg-Schaapskooi, burial pit no. 12, part of the assemblage showing flint, hammerstone, and two (of three) incomplete polishers, all red-stained (photo L.P. Louwe Kooijmans).

as compared to the more general artefact collection. There is no explanation for the underrepresentation of cores / blocks in the upper fills. So the colouring has been a process in the fill after the objects had been embedded. Quarrying natural red sand can in comparison be considered improbable. We must conclude that the red sand had not been brought in from natural occurrences elsewhere, but, in spite of the objections of the soil scientists, had formed in situ by the dissolution of some kind of red powder. As a consequence the present-day extent and intensity do not reflect the former situation but are the result of diffusion in the course of time by percolating groundwater and biological activity, which is supported by their diffuse appearance. The downward diffusion is moreover supported by the position of deposited objects, in sharp horizons halfway this red sand (see below).

In two examples diffuse grey discolouration of the natural sand at the base of the pits have been interpreted as 'foot wells' to accommodate the lower limbs of buried corpses. This can be seen in sections through pits nos. 91 and 93 . The discolouration extended to $10-20 \mathrm{~cm}$ below the base of the red-stained units and protruded a further $20 \mathrm{~cm}$. This phenomenon has been viewed as the lowest part of the pits themselves, with a fill similar to those of the shafts but lacking traces of later bioturbation. The fact that they had been dug in both cases at the eastern side of the pit was used as an argument in support of the foot well interpretation: both bodies would have been seated on the western side, facing east. The field drawings of no. 93 tell us, however, that the 'foot well' was not located in the eastern part, but right below the centre of the pit and below the deposited artefacts (cf. Fig. 5b). Only half of it was recovered after sectioning, when lowering the second half of the pit fill, giving the impression of semicircular shape (contra Verlinde \& Newell, 2006: 166). This observation weakens the argument. The fact that the ochre layers extended all over these 'foot wells' implies that the bodies would have been placed in their graves and the pits partly filled before the ochre had been scattered over the uncovered part of the bodies. The grave gifts would have been placed at the same time at a 'deposition level' half way down the present extent of the red-stained sand (see next section). 

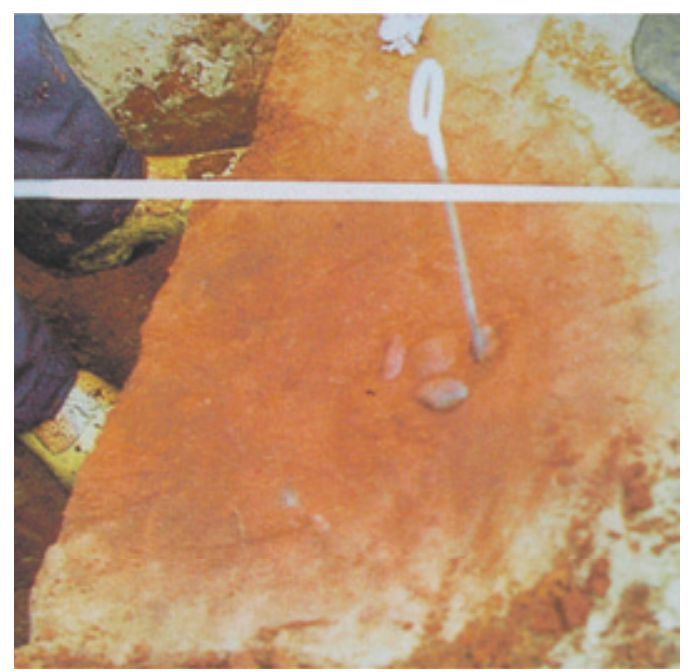

Figure 8. Mariënberg-Schaapskooi, deposition level of burial pit no. 93 during excavation, showing red-stained sand and shaft polishers with hammerstone in situ (photo L. Timmerman).

Although the above representation may not be totally improbable, there is a more likely alternative. There may have been some digging and soil disturbance at the base of the pits, but the diffuse grey colouring, on the other hand, may very well be conceived as a secondary phenomenon. The colours differ from those of the shaft fill, having a distinctly lighter hue, which equals that of the transition zone of this fill and the surrounding unaltered coversand (Fig. 5a). It would also explain why finds (settlement waste) are apparently absent in this unit, as are traces of ochre. Secondly the idea of a distinct horizontal deposition level (see section on 'Deposited artefacts') and the genesis of the red-stained sand proposed above seem to conflict with the idea of a half-filled pit and a half-covered body. Moreover, it would imply a body posture that is not documented in other sitting graves elsewhere in Europe. Accepting a natural explanation for the grey colouring below the red staining would make the graves more uniform (see Table 1) and may be preferred to the idea of supposed foot wells below other burials as well, that were apparently overlooked during excavation because they were difficult to identify (Verlinde \& Newell, 2006: 166).

It is argued that anomalies in four pits at the top of the red-stained sand "might indicate the position of the corpses and of the bent knees" (ibidem.: 168). That corpses would be reflected is however not obvious from the published drawings and even less from the colour slides which give a better idea of conditions. In two cases the patterns result clearly from the way the body of red sand had been levelled in excavation (nos. 91 \& 93). In the case of grave pit no. 55 some ochre seems to have been washed in (or scattered) after the shaft was half-filled. The claimed striking upward bulges at the top of the red-stained sand in no. 12 should be used with caution, as these are based on oral

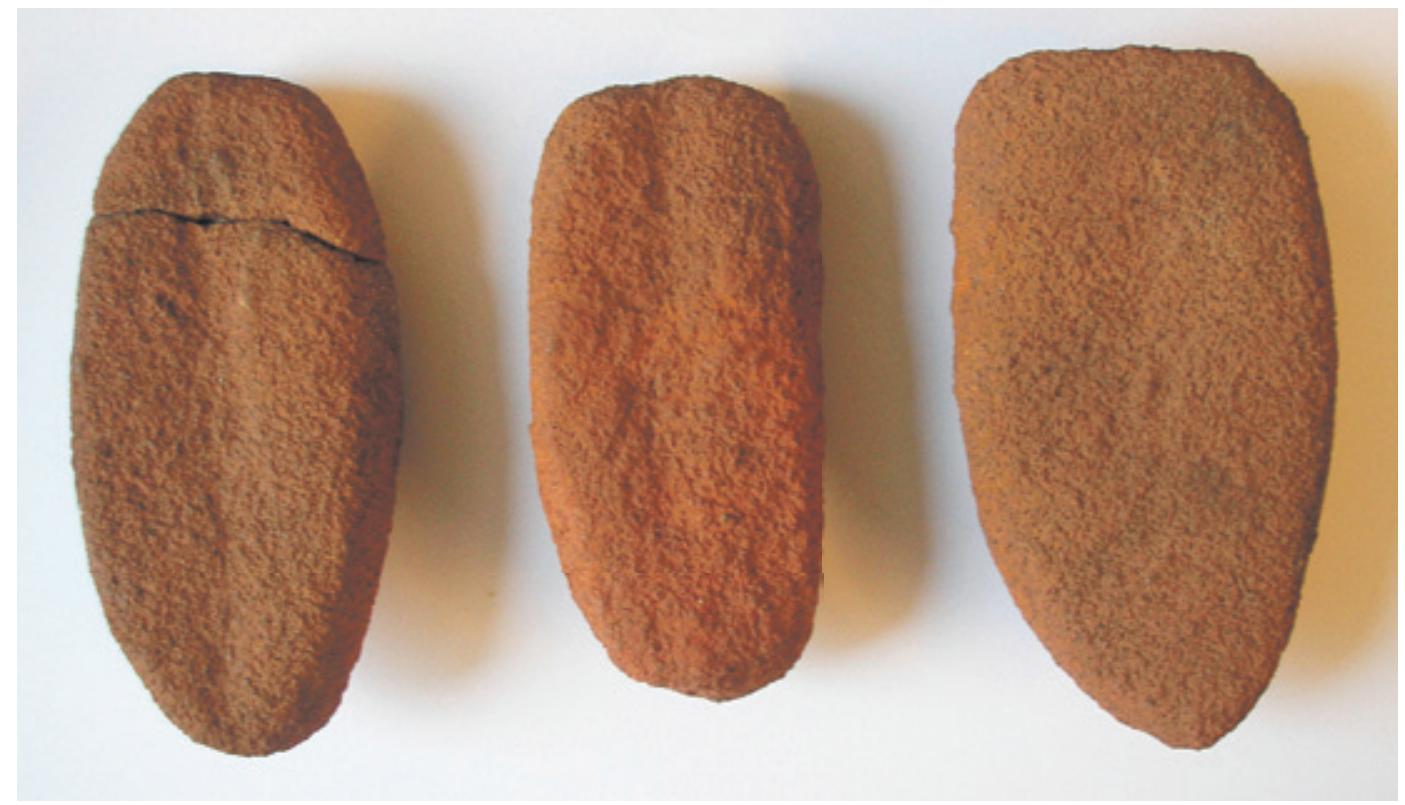

Figure 9. Mariënberg-Schaapskooi, burial pit no 93. Blanks for shaft polishers, red-stained (photo L.P. Louwe Kooijmans). 
Table 5. Mariënberg-Schaapkooi, deposited artefacts in the burial pits as recorded on the field plans and as reported.

\begin{tabular}{|l|c|}
\hline Burial pit no. & 12 \\
\hline $\begin{array}{l}\text { On field plan }(f) \\
\text { In publication }(p)\end{array}$ & $p$ \\
\hline Polishers & 3 \\
\hline (Hammer) stones & 1 \\
\hline Blade (fragment)s & 3 \\
\hline Core / blocks & 2 \\
\hline Total & 9 \\
\hline
\end{tabular}

\begin{tabular}{|c|c|}
\hline \multicolumn{2}{|c|}{55} \\
\hline$f$ & $p$ \\
\hline- & - \\
\hline- & - \\
\hline 3 & 3 \\
\hline- & - \\
\hline 3 & 3 \\
\hline
\end{tabular}

\begin{tabular}{|c|c|}
\hline \multicolumn{2}{|c|}{90} \\
\hline$f$ & $p$ \\
\hline- & - \\
\hline- & - \\
\hline- & - \\
\hline- & - \\
\hline$o$ & $o$ \\
\hline
\end{tabular}

\begin{tabular}{|c|c|}
\hline \multicolumn{2}{|c|}{91} \\
\hline$f$ & $p$ \\
\hline- & - \\
\hline- & - \\
\hline 7 & 7 \\
\hline- & - \\
\hline 7 & 7 \\
\hline
\end{tabular}

\begin{tabular}{|c|c|}
\hline \multicolumn{2}{|c|}{92} \\
\hline$f$ & $p$ \\
\hline- & - \\
\hline 1 & 1 \\
\hline 8 & 6 \\
\hline 1 & 1 \\
\hline 10 & 8 \\
\hline
\end{tabular}

\begin{tabular}{|c|c|}
\hline \multicolumn{2}{|c|}{93} \\
\hline$f$ & $p$ \\
\hline 3 & 3 \\
\hline 1 & 2 \\
\hline 17 & 14 \\
\hline 3 & 3 \\
\hline 24 & 22 \\
\hline
\end{tabular}

information only. The true situation may have been more similar to nos. 91 and 93 than in the schematic reconstruction. All patterns can be easily explained by incidental differences in the formation process of the red staining. That red sand was found (slightly) shifted to the west in no. 92, and at the west side only in the section over no. 90 (the 'child's grave') may very well reflect an original asymmetrical deposition and as such relate to the position of a corpse. But the link with the questionable 'foot wells' should be abandoned.

One may in general observe how in the course of the argument suggestions become facts, which in their turn are then quoted by others. I conclude that neither these anomalies nor the apparent asymmetry may be used to prove that the pits concerned are graves, nor inform us in a positive sense about Mesolithic burial postures.

\section{Deposited artefacts}

Flint artefacts have been found randomly distributed in the fill of the pit features, in the fill of the shafts as well as in the red-stained sand. These flints have the same characteristics as the material found at the surface all over the site; technologically these are of poor quality, of small dimensions and mainly burned. Such finds were interpreted as Mesolithic settlement waste in secondary position and because of this their positions were not plotted on the detailed field plans during excavation. In the ochre layer, in contrast, artefacts were found that are more conspicuous and / or occurred together in small groups, in each case at a very distinct level halfway within the red-stained unit (Fig. 6). During the excavation they were recognised as specially deposited and were therefore individually plotted and often given precise depth measurements. The deposition level in three of the four cases formed a well-defined horizon, c. $20 \mathrm{~cm}$ above the base of the red staining, in one case (no. 55) more than 8 $\mathrm{cm}$ above, which may relate to the less developed ochre staining in this feature. One may safely assume that this restricted level of deposition indicates an original surface i.e. the bottom of the pit, made invisible by the dominant red colouring.

The presumably intentionally deposited flint comprises mainly unworked blades and some nodules / flake cores, with only three retouched artefacts: two obliquely truncated blades (in burial pits nos. 55 and 93) and a b-point (in no. 91). Their relatively large dimensions and better quality, compared to settlement discard, and the nature of the artefacts are in agreement with the more general statement by Judith Grünberg (2000:114) that Mesolithic lithic grave gifts often appear to have been above average in dimension and mainly represent implements for daily duties, with a dominance of flint blades. There appear to be hardly any differences between the published 'accoutrements' and those mapped in the field. Only five (small) blades that were mapped were later apparently rejected (Table 5).

The shaft polishers play a prominent role in the argumentation, since they were found in sets of three in two features (nos. 12 \& 93) at the deposition level within the red-stained sand (Fig. 8). Four polishers are made of a rather loose and coarse sandstone, the two others of a similar sandstone, but rich in small rounded pebbles. They are thin $(2-3 \mathrm{~cm})$, flat and oval in shape with (partly reconstructed) lengths of $8.6-11.5 \mathrm{~cm}$. Those in no. 93 were found adjacent, in the centre of the ochre layer, with their grooves downwards. Those in no. 12 were similarly reported to have been lying adjacent, in the ochre layer, and with 
(one of) their flat sides downward (Verlinde \& Newell, 2006: 156, $163 \&$ 168). These artefacts are considered to have been intentionally deposited on the basis of their exclusive occurrence in these features (only one additional fragment was recovered from hearth no. 15) and their apparently special arrangements, and I don't see any counterarguments against this view. It is however questionable whether we may consider these objects as 'accoutrements' of a burial: material deposited as grave gifts to accompany a buried person. Firstly the specimens from grave pit no. 12 are all broken and deposited in an incomplete state, which may be considered unusual for a grave gift in a Mesolithic context (Fig. 8). One of the specimens from grave pit no. 93 is broken, but both parts were recovered (Fig. 9). We should realize that breaking such stones does not occur casually, but needs rather strong forces and will have been done intentionally. Secondly, the stones are labelled 'shaft polishers' but the grooves, characteristic for this type of implement, are very shallow to absent. In the last case the stones have been interpreted as spare blanks, but in essence all grooves are so superficially executed, consisting of scratches only in most cases, that they all may be considered blanks or preforms, not yet suited for actual use. The drawings are in this respect somewhat misleading, as may be apparent from the sections drawn. The single exception may be one specimen from no. 12. The small fragment from hearth no. 15 is in contrast part of a (much smaller) well-finished tool. Thirdly, to the author no examples are known of grave gifts comprising three shaft polishers. The tool may occur in pairs - which gave rise to call them 'arrow shaft straighteners' - or singly, showing that they may very well function on their own as well.

Shaft polishers are a type of artefact used 'throughout the ages', from the Upper Palaeolithic to Beaker times, be it in different shapes. Parts of comparable oval shaft polishers have for instance been found at the Ahrensburg site Geldrop 3-1 (Deeben, 1995) and at HardinxveldDe Bruin, in between refuse of phase 2, dated to $5100-4800$ cal BC (Van Gijn \& Houkes, 2001). The shaft polishers have been used as an additional argument in dating the burials. However they are not known as grave gifts in the European Mesolithic (see section on 'External references') and only occur irregularly as grave gifts in the earlier Neolithic of the Middle Rhine area. They are not found in the LBK, but in the subsequent GGK and RK phases, nor do they occur in the nearby LBK cemeteries of Elsloo and Niedermerz, respectively in southern Limburg and the Rhineland (Modderman, 1970; Dohrn-Ihmig, 1983). Claims for the connection of this custom with Mariënberg thus run up against distance and age differences (contra Verlinde \& Newell, 2005: 16; 2006: 169), even if a phase 4 date for the Mariënberg burials were to be assumed. More puzzling than the age are however the association of the implements in a burial context. Intentional deposition outside the sphere of human burial may be an alternative, but would be without precedent in the Mesolithic and would conflict with the deliberate use of red ochre in the pits.

In all nine hammerstones have been found at the site, four of which occur in the deposition levels of pits nos. 12, 91 and $93 .{ }^{11}$ There can be no doubt that these four belong to the deposited material.

\section{Reinterpretations}

Quite a number of adjustments to the earlier interpretations of the Mariënberg features are proposed in this paper, most of them contrary to those put forward in the site report (Verlinde \& Newell, 2006). The reader may judge for him or herself which arguments and conclusions may last and which not. I list these in nine points:

1) The dating is more feasibly within phase 3 or in the hiatus $3 / 4$, around 6000 cal BC, implying an asynchronous relationship with domestic spaces, or outside the period of domestic use and well before possible Neolithic contacts.

2) The soil discolourations of the 8000 -yearold features have to be understood in terms of taphonomic processes and site formation models.

3) The former shaft diameters were slightly smaller than recorded.

4) The bases of the pits equate with the restricted levels of deposited artefacts, as documented in the field, making most pits shallower.

5) The red-stained sand is not redeposited natural 'red sand', but the result of dissolution and diffusion of a red substance 
('ochre') from an unknown source, deposited at the same restricted level.

6) The idea of deposited bodies is purely hypothetical and cannot be positively identified through anomalies in the top of the red-stained sand, nor in the asymmetry of the pits.

7) 'Foot wells' have to be rejected as an interpretation. They are most probable the result of natural soil processes below the pit's fills.

8) The 'funnels' in general will be the result of caving in of the pit rims. The most prominent 'funnel' (of feature no. 12) most likely represents a Late Neolithic grave, with a long blade as a grave gift.

9) The shaft polishers are in fact (partly broken) blanks for polishers, not finished implements, and as such would be rather peculiar as grave gifts.

We still are faced with the problem that the pits have diameters in the upper ranges of other pit types, are of greater depth and have ochre and artefacts deposited at their bottoms. The artefacts found in the pits also represent a special selection of finds in relation to the Mesolithic settlement waste which contains few such items. The pits were doubtless used for intentional deposition, and the ochre and the lack of examples of such pits in the Mesolithic, inevitably points in the direction of the burial of human corpses. However, the combination of cylindrical pit shapes, their clustering, and the association of ochre and polishers, makes them very unusual not only within the Lower Rhine Area, but for the European Mesolithic as a whole.

\section{External references}

\section{The Lower Rhine Area}

Mesolithic formal burials in the Lower Rhine Area are confined to six cremations at Oirschot (Arts \& Hoogland, 1987), Dalfsen (Verlinde, 1974), Rotterdam (Zijl et al., 2011), four inhumations with preserved skeletal material at Hardinxveld-Polderweg and De Bruin (Louwe Kooijmans, 2007), and a recently excavated burial at Swifterbant, all wetland areas. The inhumations comprise four extended examples, one of which (De Bruin no. 2) is definitely a seated burial. In one of the four pits-with-cremations, recently excavated near Rotterdam, a grinding stone and a broken Geröllkeule ('hour glass' perforated pebble or mace-head) were found, which might be viewed as a parallel case to the broken and unfinished polishers of Mariënberg (Niekus, pers. comm.). A more common way of treating the dead - but only documented under optimal conditions of preservation and hard to specify - was as dispersed remains within domestic refuse, as documented at both Hardinxveld sites, especially Polderweg phase 1 (Louwe Kooijmans, 2001a, b).

All burials $(n=30)$ of the subsequent Swifterbant culture - the direct successor of the Late Mesolithic societies - are extended and supine inhumations without grave gifts, except occasionally some beads (Raemaekers et al., 2007; Smits \& Van der Plicht, 2009). So the presumed burial function of the Mariënberg features do not fit in any way into the regional burial customs, as varied as these may be, and with the exception of the single burial at De Bruin.

To better evaluate the Mariënberg evidence a wider overview is required.

\section{Burial postures}

It has already been demonstrated that the Mariënberg burial pits are matched by a small series ( 8 sites with 9 burials) of 'funnel-shaped sitting inhumations', extending from Southern France to Southern Sweden (Verlinde \& Newell, 2006: 177). Within the specific selection of pit variables the Mariënberg-Schaapskooi cluster forms a subgroup of its own, characterized by the (disputed) foot wells, ochre, a b-point, polishers and hammer stones (ibidem.: 181). The authors concluded that these sitting burials should represent a specific pan-tribal lineage or clan, even a group of 'wandering shamans' (Verlinde \& Newell, 2005: 13; Verlinde \& Newell, 2006: 200).

This view may however be slightly more nuanced with the help of the European survey of Mesolithic graves by Judith Grünberg and her more recent paper on the sitting graves (Grünberg, 2000, 2008). She compiled a European corpus of c. 2100 Mesolithic individuals from 202 sites, cemeteries as well as isolated graves (i.e. not more than 2 burials cooccurring). 


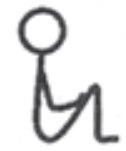

1

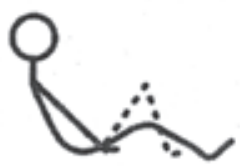

3

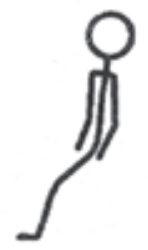

5

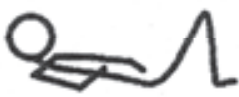

7

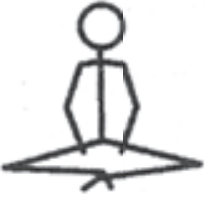

2

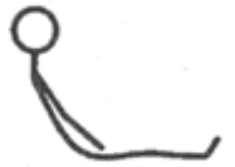

4

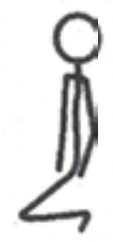

6

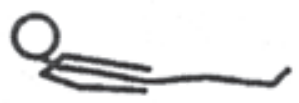

8
Figure 10. Eight variants in the sitting and half-sitting Mesolithic burial posture (source Grünberg, 2008: Fig. 3).

The sitting posture in general appears to be rather uncommon, especially in cemeteries, with only $13 \%$ or 67 of a total of 504 individuals buried in this position. For single graves the percentage is nearly twice as high, that is 17 out of 71 burials or $24 \%$ of all cases (Grünberg, 2000: 67, Table 23; 2008). ${ }^{12}$ Examples are widely dispersed, from Portugal and Sicily to Karelia, and from Brittany to the Iron Gates Gorge, and ranging in time from the Preboreal to the Late Atlantic, a period of c. 5000 years. Everywhere it is treated just like an alternative burial option. This is especially apparent in the communal cemeteries.

Eight variants in sitting posture have been distinguished (Fig. 10). Dominant is the 'normal' upright posture with contracted legs (no. 1) found in single graves or very small cemeteries of 2-3 burials all over France and Germany, with outliers as far apart as Gotland, Sicily and southern Russia (Fig. 11 \& Table 6). In the quasi absence of cemeteries or in areas where Mesolithic burials are scarce the sitting posture is still largely dominant as for example in Germany and France, with scores of about 50\% (Grünberg, 2000: Fig. 74). This does not mean however that it was a common way of dealing with the dead. The alternatives may be (far) less visible archaeologically.

All other variants occur predominantly (but not exclusively) within the major cemeteries, where extended burials prevail. The rare 'standing' posture no. 5 is restricted to four cases in the large cemetery of Olenij ostrov (Karelia), the 'tailor's posture' no. 2 is found only in Austria and in the Iron Gates Gorge sites, the (half-)sitting postures with extended legs (nos. $4 \& 8$ ) are found exclusively in southern Sweden (Skateholm), a rare kneeling posture (no. 6) was practised in the same region. It seems that communities spaced widely apart developed their own practice of a more general custom. A major exception to this 'rule' are the cemeteries of southern Brittany (Téviec and Hoëdic), where all dead have been buried (half-)seated with contracted legs (nos. 3 \& 7), as seems also to be the case in the Tagus estuary (e.g. Moita do Sebastião). As cemeteries of predominantly (half-)sitting graves they are the only parallels for the Mariënberg cluster all over Europe.

\section{Pit shapes and dimensions}

The shapes of sitting graves vary from round or almost square to oval, and their sections are often conical (Table 6; Grünberg, 2008: 47). Diameters range between 50 and c. $200 \mathrm{~cm}$, while the depths generally vary between 20 and $160 \mathrm{~cm}$. Larger graves accommodated multiple burials, the smallest graves children. The recorded depths have limited significance since the reference level is rarely mentioned, nor has erosion been estimated.

The shapes, corrected diameters and depthsbelow-former-surface of the Mariënberg features fit this description (Table 6), and are in line with the conclusions of Newell based on a smaller sample. Diameters are also in accordance with those of the Brittany cemeteries, where depths are however considerably shallower. This can easily be explained by the different conditions of shell middens on hard rock in the French examples, as opposed to the coversand of Mariënberg. 


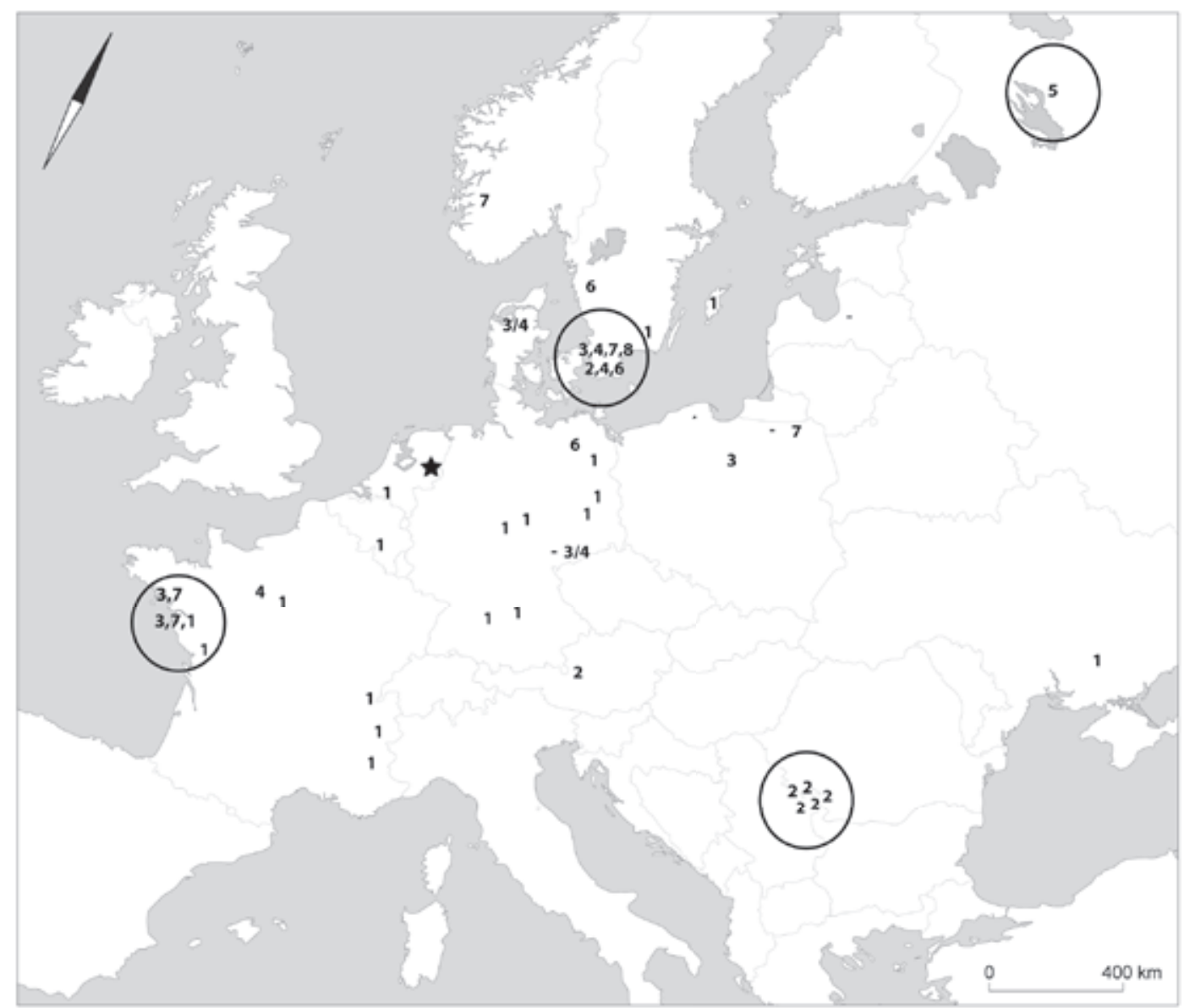

Figure 11. Mesolithic sitting postures (see Fig. 10) north of the Mediterranean. Major cemeteries encircled. Mariënberg indicated with a star. Data from Grünberg, 2008: Appendix 1 \& 2. Certain and uncertain cases treated equally. Cf. Table 6 in this paper (map J. Porck).

\section{Ochre}

The use of ochre in burial ritual is equally widespread all over Europe - albeit rarely in the South and Southeast - and throughout the Mesolithic, from its earliest stages until its end (Grünberg, 2000: 142-149 \& 168; 2008: 55). In the Late Mesolithic it is most frequently and most intensively utilised in the Northeast: in Northwest Russia, the Baltic and Scandinavia. The majority of the burials at Skateholm I and II (Southern Sweden) showed ochre, in extended as well as seated burials; in the large cemetery of Zvejnieki (Latvia) (traces of) ochre were found in $70 \%$ of the 145 burials; at Olenij ostrov (Northwest Russia) the total was even higher with ochre in $93 \%$ out of 177 burials and occasionally represented by ochre deposits up to $15 \mathrm{~cm}$ thick. In Central Europe ochre was profusely applied at some of the isolated seated burials: a layer of $30 \mathrm{~cm}$ occurs in the exceptional
Bad Dürrenberg grave (Sachsen-Anhalt), a layer of $19 \mathrm{~cm}$ at Niederkaina (Sachsen), and in two burials, $15 \mathrm{~m}$ apart, at Bottendorf (Thüringen). But many other seated burials, in Sweden and Germany, did not show any traces. In Western Europe the use of ochre was less intense, but most of the seated and half-seated interments at Téviec and Hoëdic (Brittany) showed some ochre, be it in modest amounts.

Of interest as a reference for Mariënberg, with respect to ochre and grave gifts, are the rescued burials from the small cemetery of Schöpsdorf 2 (Sachsen). No skeletal remains had been preserved, but the oblong pits suggest horizontal postures. In all four burials ochre was used, with a concentration at one of the end of each grave in three cases. Grave gifts comprised nil, four, five and 19 flint blades. $\mathrm{A}{ }^{14} \mathrm{C}$ date of $8210 \pm 70$ BP (Bln-2998) of a buried soil would give a terminus post quem for the burials. 
Table 6. Mesolithic sitting graves in Northwest and Central Europe. Data from Grünberg, 2008: Appendix 1 \& 2. Mariënberg data from Table 1 (proposed diameter \& original depth). Key: ()$=$ uncertain, $-=$ absent or not documented, $f=$ female, $m=$ male, ad = adult, juv = juvenile, coll = collective

\begin{tabular}{|c|c|c|c|c|c|c|c|c|}
\hline Site & $\begin{array}{c}\text { Feature } \\
\text { no. }\end{array}$ & $\begin{array}{c}\text { Diameter } \\
\text { or } 1 \times b\end{array}$ & $\begin{array}{c}\text { Reported } \\
\text { depth }\end{array}$ & Posture & Ochre & $\begin{array}{l}\text { Burial } \\
\text { gifts }\end{array}$ & $\begin{array}{l}\text { Orna- } \\
\text { ments }\end{array}$ & $\begin{array}{l}\text { Physical } \\
\text { anthrop. }\end{array}$ \\
\hline \multicolumn{9}{|l|}{ Lower Rhine Area } \\
\hline Mariënberg & 12 & 80 & 150 & - & + & 9 & - & - \\
\hline & 55 & 80 & 95 & - & + & 3 & - & - \\
\hline & 90 & 55 & 70 & - & + & - & - & - \\
\hline & 91 & 120 & 115 & - & + & 7 & - & - \\
\hline & 92 & 80 & 67 & - & + & 8 & - & - \\
\hline & 93 & 90 & 55 & - & + & 22 & - & - \\
\hline Hardinxveld-De Bruin & 2 & $156 \times 124$ & $>32$ & 1 & - & - & - & $\mathrm{m}$ \\
\hline Abri des Autours & 2 & - & - & 1 & - & (7) & - & 1 of coll \\
\hline
\end{tabular}

France / Germany

\begin{tabular}{|c|c|c|c|c|c|c|c|c|}
\hline Auneau & 6 & $160 \times 140$ & - & 4 & + & 13 & - & $\mathrm{m}$ \\
\hline Villeneuve & & $230 \times 180$ & 60 & 1 & - & 1 & - & 1 of coll \\
\hline La Vergne & 3 & $>45 \times 35$ & 35 & $1+1$ & + & - & $>814$ & f \& juv \\
\hline Bad Dürrenberg & & $90 \times 55$ & $>50$ & $(1)+(1)$ & + & 51 & 69 & f \& juv \\
\hline \multirow[t]{4}{*}{ Bottendorf } & 1 & 67 & $100-110$ & 1 & + & 2 & - & $\mathrm{m}$ \\
\hline & 2 & $80 \times 120$ & $>50$ & $1+?$ & + & - & - & ad \& juv \\
\hline & $2 a$ & - & - & (1) & - & - & - & juv \\
\hline & 3 & - & - & 1 & - & - & - & juv \\
\hline Kolberg & & $115 \times 105$ & C. 100 & 1 & - & 1 & - & $f$ \\
\hline Plau & & - & - & (6) & - & 1 & 5 & $\mathrm{~m}$ \\
\hline Rothenklempenow & & - & - & 1 & - & - & - & $f$ \\
\hline $\begin{array}{l}\text { Niederkaina- } \\
\text { Schafberg }\end{array}$ & & 285 & 165 & - & + & (34) & $(-)$ & - \\
\hline Schöpsdorf 2 & 4 & $135 \times 100$ & - & - & + & (5) & $(-)$ & - \\
\hline Nehringen & $1-3$ & - & - & (1) & + & - & - & - \\
\hline
\end{tabular}

Bretagne

\begin{tabular}{|l|c|c|c|c|c|c|c|c|}
\hline Hoëdic & B & $110 \times 80$ & - & $(7)$ & - & - & - & $f$ \\
\hline (6 of 14 ind.) & H & $90 \times 70$ & 50 & 3 & + & 3 & 588 & $f$ \\
\hline & J & $150 \times 80$ & - & $7+(7)$ & - & 8 & 765 & $\mathrm{f} \&$ juv \\
\hline & $\mathrm{K}$ & - & 70 & 7 & + & 5 & 553 & $\mathrm{~m}$ \\
\hline & $\mathrm{L}$ & - & - & 7 & - & 2 & 248 & $\mathrm{f}$ \\
\hline Téviec & $\mathrm{A}$ & $90 \times 70$ & $10-15$ & $3+3$ & + & 3 \& 6 & 3 \& 588 & $\mathrm{f} \& \mathrm{~m}$ \\
\hline (12 of 23 ind.) & $\mathrm{D}$ & $100 \times 60$ & 20 & $3+(3)$ & + & 14 & 72 & $\mathrm{f} \&$ juv \\
\hline & $\mathrm{E}$ & $82 \times 74$ & - & $3+(3)$ & + & 7 & 1689 & $\mathrm{~m} \&$ juv \\
\hline & $\mathrm{H} 2$ & $90 \times 85$ & - & 7 & + & $(7)$ & 577 & $\mathrm{f}$ \\
\hline & $\mathrm{J}$ & - & 30 & $3+(3)$ & - & $>2$ & - & $\mathrm{f} \&$ juv \\
\hline & $\mathrm{K} 1 \& 6$ & 100 & - & $7+7$ & + & $4 \&>13$ & $>1 \& 301$ & 2 of coll \\
\hline & $\mathrm{M}$ & $60 \times 55$ & 45 & 1 & - & 37 & 315 & $\mathrm{~m}$ \\
\hline
\end{tabular}

Alpine caves / rock shelters

\begin{tabular}{|l|c|c|c|c|c|c|c|c|}
\hline Bocksteinhöhle & & $>50 \times 50$ & $>60$ & $(1)+1$ & + & - & - & $\mathrm{f} \&$ juv \\
\hline Büttnerloch & & - & - & 1 & - & - & - & $\mathrm{f}$ \\
\hline Sous Balme & 1 & - & - & $(1)$ & - & 5 & 22 & $\mathrm{~m}$ \\
\hline & 2 & c. 75 & c. 48 & 1 & + & 2 & 1 & $\mathrm{~m}$ \\
\hline Sous Sac & & - & - & 1 & - & - & - & $\mathrm{m}$ \\
\hline Grotte Joëlle & & - & - & $(1)$ & + & 6 & - & $\mathrm{m}$ \\
\hline Zigeunerhöhle & & c. 35 & 40 & 2 & - & $(-)$ & $(-)$ & juv \\
\hline
\end{tabular}


Table 6, continued. Mesolithic sitting graves in Northwest and Central Europe. Data from Grünberg, 2008: Appendix 1 \& 2. Mariënberg data from Table 1 (proposed diameter \& original depth). Key: ()$=$ uncertain, $-=$ absent or not documented, $f=$ female, $m=$ male, ad $=a d u l t, j u v=$ juvenile, coll = collective.

\begin{tabular}{|c|c|c|c|c|c|c|c|c|}
\hline Site & $\begin{array}{c}\text { Feature } \\
\text { no. }\end{array}$ & $\begin{array}{c}\text { Diameter } \\
\text { or } 1 \times b\end{array}$ & $\begin{array}{c}\text { Reported } \\
\text { depth }\end{array}$ & Posture & Ochre & $\begin{array}{l}\text { Burial } \\
\text { gifts }\end{array}$ & $\begin{array}{l}\text { Orna- } \\
\text { ments }\end{array}$ & $\begin{array}{l}\text { Physical } \\
\text { anthrop. }\end{array}$ \\
\hline \multicolumn{9}{|l|}{ Poland } \\
\hline \multirow[t]{4}{*}{ Dudka } & 2 & - & - & - & + & - & - & coll \\
\hline & 11 & - & - & (7) & + & - & - & - \\
\hline & 13 & - & - & - & + & - & - & coll \\
\hline & 14 & - & - & - & + & - & - & ad \\
\hline Janisławice & & - & 98 & 3 & + & 57 & 27 & $\mathrm{~m}$ \\
\hline Mszano & 4 & 50 & 60 & - & + & - & - & - \\
\hline Wóźna Wieś & & & & & & - & - & $\mathrm{m}$ \\
\hline \multicolumn{9}{|l|}{ S Scandinavia } \\
\hline Fannerup & & - & - & $(3 / 4)$ & + & $(-)$ & (1) & $\mathrm{m}$ \\
\hline Bäckaskog & & $50 \times 60$ & 120 & 1 & - & 2 & - & $f$ \\
\hline Uleberg & & $135 \times 80$ & 90 & $(6)+(6)$ & - & - & - & $f \& m$ \\
\hline \multirow[t]{2}{*}{ Lumelunda-Kams } & 1 & & 86 & 1 & - & - & - & $\mathrm{m}$ \\
\hline & 3 & C. 60 & 100 & 1 & - & 5 & - & $\mathrm{m}$ \\
\hline Skateholm I & 2 & - & - & 7 & + & - & - & $\mathrm{m}$ \\
\hline \multirow[t]{9}{*}{ (11 of 62 ind.) } & 3 & - & $>30$ & 3 & + & - & - & $f$ \\
\hline & 5 & $160 \times 70$ & 40 & 8 & + & 1 & - & $\mathrm{m}$ \\
\hline & 6 & $130 \times 60$ & & $4+4$ & + & - & 33 & f \& juv \\
\hline & 16 & $170 \times 80$ & $>10$ & 8 & + & 1 & 32 & $\mathrm{~m}$ \\
\hline & 25 & $130 \times 50$ & 20 & 4 & + & - & - & $f$ \\
\hline & 32 & $160 \times 80$ & 20 & - & + & 1 & - & $\mathrm{m}$ \\
\hline & 39 & $90 \times 50$ & - & $3 / 4$ & + & - & - & ad \\
\hline & 48 & $140 \times 110$ & 30 & 4 & + & - & - & ad \\
\hline & 54 & $200 \times 120$ & 30 & $3 / 4$ & + & - & - & ad \\
\hline Skateholm II & II & $130 \times 70$ & 50 & 4 & - & 4 & - & $\mathrm{m}$ \\
\hline \multirow[t]{5}{*}{ (7 of 22 ind.) } & VIII & - & 40 & 4 & - & - & C. 102 & $f$ \\
\hline & $x$ & $250 \times 120$ & 60 & 4 & + & $4 \& 2$ & $1 \&>10$ & $m \& m$ \\
\hline & XII & - & - & $(6)+(6)$ & + & $1 \& 2$ & $-\&-$ & juv \& juv \\
\hline & $\mathrm{XV}$ & $230 \times 130$ & - & 4 & + & $>6$ & $>18$ & $\mathrm{~m}$ \\
\hline & XXII & $100 \times 90$ & 40 & 2 & - & - & 41 & $f$ \\
\hline Viste & & C. $1 \mathrm{~m} 2$ & & (7) & - & - & - & $\mathrm{m}$ \\
\hline
\end{tabular}

We conclude that the use of ochre was a common practice and that Mariënberg was no exception. Its use fits the wider pattern, with geographical connections in all directions. The intensity at Mariënberg may however be difficult to compare directly, in view of the supposed later soil processes.

\section{Grave gifts}

How 'rich' are the Mariënberg burial inventories, and how do these fit into the present body of knowledge on Mesolithic grave gifts? This question becomes more relevant when we realise that only lithics are preserved at this site and yet there is a common perception that non- lithic implements and ornaments of organic substances were customary grave gifts in the Mesolithic.

In fact, in general Mesolithic graves are relatively poor in such finds. According to Grünberg's survey $56 \%$ had none at all, only $10 \%$ may be considered relatively rich, with $>2$ implements and $>10$ ornaments, and there is hardly any difference between isolated burials and those in cemeteries (Grünberg, 2008: Fig. 6). Sitting graves as a group are considerably better equipped, with grave gifts in two thirds of all cases, half of which score as 'rich' with $>2$ implements and $>10$ ornaments. ${ }^{13}$ A few of the sitting graves are 'extremely rich'. For 
Table 7. Téviec, Morbihan (Brittany), Mesolithic cemetery. Data from Grünberg, 2000 (II), with addition of posture codes after Grünberg, 2008. Key: $\mathrm{s}=$ sitting, $\mathrm{h}=$ half sitting, $\mathrm{e}=$ extended and supine (lying stretched).

\begin{tabular}{|c|c|c|c|c|c|c|}
\hline \multirow{3}{*}{ No. } & \multicolumn{2}{|c|}{ Grave } & \multicolumn{4}{|c|}{ Skeleton } \\
\hline & \multirow{2}{*}{$L \times B$} & \multirow{2}{*}{ Depth } & \multirow{2}{*}{ Phys. anthr. } & \multicolumn{2}{|c|}{ Posture } & \multirow{2}{*}{ Ochre } \\
\hline & & & & 2000 & 2008 & \\
\hline $\mathrm{A} 1$ & \multirow{2}{*}{$90 \times 70$} & \multirow{2}{*}{$10-15$} & $f$ & s & 3 & + \\
\hline $\mathrm{A} 2$ & & & $\mathrm{~m}$ & $\mathrm{~s}$ & 3 & + \\
\hline B & $100 \times 60$ & 20 & $f$ & s & - & ++ \\
\hline C & $50 \times 35$ & $<10$ & 3 juv & e & - & ++ \\
\hline D & $100 \times 60$ & 20 & f\& juv & s & $3 \&(3)$ & + \\
\hline $\mathrm{E}$ & $82 \times 74$ & $?$ & $m \&$ juv & $\mathrm{s}$ & $3 \&(3)$ & + \\
\hline $\mathrm{H} 1$ & \multirow{2}{*}{$90 \times 85$} & & f\& juv & - & - & + \\
\hline $\mathrm{H}_{1} / 2$ & & & $f$ & $\mathrm{~s}$ & 7 & + \\
\hline J & & & f\& juv & s & $3 \&(3)$ & - \\
\hline K1 & \multirow{6}{*}{$120 \times 130$} & & $\mathrm{~m}$ & h & 7 & + \\
\hline K2 & & & $\mathrm{m}$ & - & - & + \\
\hline $\mathrm{K}_{3}$ & & & $f$ & - & - & + \\
\hline K4 & & & $f$ & e & - & + \\
\hline $\mathrm{K}_{5}$ & & & $\mathrm{f}$ & - & - & + \\
\hline K6 & & & $\mathrm{m}$ & $\mathrm{h}$ & 7 & + \\
\hline L & $50 \times 35$ & $<10$ & juv & - & - & ++ \\
\hline$M$ & $60 \times 55$ & 45 & $\mathrm{~m}$ & h & 1 & - \\
\hline
\end{tabular}

\begin{tabular}{|c|c|c|c|c|c|c|}
\hline \multicolumn{7}{|c|}{ Grave gifts } \\
\hline \multicolumn{2}{|c|}{ Flint } & \multicolumn{2}{|c|}{ Stone } & \multicolumn{2}{|c|}{ Bone/antler } & \multirow{2}{*}{$\begin{array}{c}\text { Shell } \\
\text { Orna- } \\
\text { ments }\end{array}$} \\
\hline $\begin{array}{c}\text { Obliq. } \\
\text { trunc. } \\
\text { blades }\end{array}$ & Other & $\begin{array}{c}\text { Hammer } \\
\text { stones }\end{array}$ & Other & Daggers & Other & \\
\hline 1 & 2 & - & - & - & - & \multirow{2}{*}{591} \\
\hline 1 & 4 & - & - & 1 & - & \\
\hline - & 5 & 1 & 1 & 1 & 1 & 194 \\
\hline 2 & 2 & - & - & 4 & 3 & 101 \\
\hline 5 & 4 & 1 & - & 2 & 2 & 72 \\
\hline 1 & 5 & - & - & 1 & - & 1,689 \\
\hline 1 & 1 & - & - & - & - & 65 \\
\hline 2 & 2 & - & - & 2 & - & 577 \\
\hline 1 & + & - & - & & - & - \\
\hline 1 & 2 & - & - & - & 1 & 2,039 \\
\hline 3 & $>4$ & - & - & 1 & 1 & 442 \\
\hline 1 & & - & - & 2 & 1 & 575 \\
\hline 3 & $5^{+}$ & 2 & - & - & 3 & 301 \\
\hline 1 & 8 & - & - & - & - & 101 \\
\hline 3 & 32 & 1 & - & 1 & - & 315 \\
\hline 26 & 67 & 5 & 1 & 15 & 12 & 7,062 \\
\hline
\end{tabular}

example, the double grave of a woman and very young child at Bad Dürrenberg contains at least 48 lithics (excluding other finds), and the burial of an adult man at Janisławice has 57 associated lithics. Both are considered burials of individuals with a special role in society, interpreted as being shaman and chief respectively.

There are in addition distinct differences in lithic grave gift tradition between major regions. Such traditions are scarce in Northern Europe. Only four out of the 84 graves of Skateholm I and II contained $>2$ implements. This contrasts with the cemeteries of Téviec and Hoëdic in Brittany, where all graves have burial gifts and 13 out of 20 score as 'rich'. The 'posture 1 burials' of Germany and France are in contrast generally poor in grave gifts. Non-sitting burials in Central Europe however regularly produced modest flint inventories, like Schöpsdorf 2, mentioned above.

The presumed burials of Mariënberg - with 49 lithics in 6 burial pits - seem to correspond in this respect rather well with the Brittany burial tradition. This matching is strengthened by the two obliquely truncated blades at Mariënberg, a type (3-5 cm long) characteristic for Téviec as well as Hoëdic, represented at these sites by 39 specimens associated with 28 individuals.

Shaft polishers are unknown as grave gifts except for six bone specimens and a 'Kiesel mit Rille' with an uncertain function in the Olenij ostrov cemetery, nor do I know of any preforms or blanks, or intentionally broken stone implements as grave gifts. The same applies for sets of three shaft polishers as grave goods in any period.

Hammerstones are regularly found only in Mediterranean burials.

\section{Téviec}

In all comparisons the famous cemetery of Téviec in Morbihan, Brittany, and to a slightly lesser extent Hoëdic, appear to offer reasonable parallels for Mariënberg. Of course there are some obvious differences such as the presence 
in the Breton sites of preserved skeletons, heavy stone grave structuring, rich burial gifts and, most spectacular of all, the profuse shell dress and body ornaments! Differences in preservation, and in local conditions and tradition certainly will have played a part, but similarities may be seen in the underlying structure of the cemetery. So it is worthwhile summarizing this evidence, partly repeating some aspects already mentioned above (Table 7).

The cemetery of Téviec was excavated in 1928-1930 in an extensive shell midden by $\mathrm{M}$. and S.-J. Péquart, and can be dated to around 5400 cal BC (Meiklejohn et al., 2010). Within an uncovered surface of c. $18 \times 18 \mathrm{~m}$ ten burials with 23 interments, were found, 0.5-3.0 m apart and clustering within 7x9 m (Grünberg, 2000: II \& Fig. 18). The burial pits measured $35 \times 50 \mathrm{~cm}$ to $120 \times 130 \mathrm{~cm}$, the largest $(\mathrm{K})$ being used for multiple burial, the smallest for (very young) children. The pits were very shallow, but the bodies had been protected with large stone slabs and the pits themselves had been reinforced with stone slabs and red deer antlers. They mostly accommodated interments in half sitting posture (variants 3 and 7). These burial postures and the shallowness of the pits may both practically relate to the rocky and shell midden substrate, which prevents any possible difference in meaning between posture types 1 and 3/7. A large majority of the skeletons were red with ochre and accompanied by rich burial gifts and ornaments, comprising flint artefacts, especially obliquely truncated blades, some hammerstones, very typical small (stylet) and larger (poignard) bone daggers and some other bone tools. Most conspicuous are the large quantities (up to 1689 associated with one interment!) of roughly perforated marine shells. The Hoëdic cemetery is in many respects comparable, but has widely divergent ${ }^{14} \mathrm{C}$ dates (Meiklejohn et al., 2010) and a different skeletal age spectrum.

The main structural differences with Mariënberg are in my opinion the depths of the pits and the (supposed) posture variants, which can be related to the local conditions, and the wealth of ornaments at Téviec. It is especially the compact layout with a close spacing of the burials at both sites, which is striking. A similar dense spacing of burials, incidentally, can be found in most other Mesolithic cemeteries outside southern Scandinavia (Grünberg, 2000: Figs. 8-19).

\section{Interpretation}

The overall spectrum of sitting graves is fairly heterogeneous across Europe. The burials contain men, women and children, and vary from very rich to findless, with and without ochre etc. (Table 6). The sitting posture seems to be related to significant individual qualities of the deceased or to circumstances of death, especially apparent in the few present in larger cemeteries. These could be further specified in some cases on the basis of physical anthropological evidence and / or burial gifts, or - in the case of cemeteries - the contrast to regular forms of burial. Mentioned above is the possibility that shamans are represented by exceptional and rich burial assemblages (e.g. Bad Dürrenberg) or in other instances indicating a leading figure in society (e.g. Janisławice and Olenij ostrov grave 100). Five cases of a double grave of a woman and very young child are mentioned as possible examples of a death during child birth, one of which is the already mentioned Bad Dürrenberg burial, but others occur at Téviec (D \& J) and in Vedbæk in Denmark. There are some cases of exceptional old age, or of above normal stature, or of extreme pathology and of violence, documented by embedded projectiles or healed trauma. An example of the latter is the adult male in grave 2 at Hardinxveld-De Bruin (Grünberg, 2008: 67; Smits \& Van der Plicht, 2009: 59 \& Fig. 2). One may assume that the special circumstances of death or social persona did not always leave archaeologically visible traces. This holds true especially for Mariënberg, where skeletal evidence is missing, as are organic burial gifts, but the unique inventory of three broken and only half-finished blanks for shaft polisher in two graves may be viewed as unconventional and exceptional material symbols, relating to the special position in society occupied by the interred person. The other burials may be viewed as relatives of less prominent social stature, but nevertheless sharing the qualification for the use red ochre.

The interpretation adopted here combines some of the ideas of Verlinde and Newell (2006: 200 \& 286) with those of Grünberg (2008). The first two suggested a pan-tribal social group - lineage or clan - as an explanation for all posture 1 burials in NW Europe. This option, however, seems a little far-fetched and the evidence quoted above indicates that the 
burials on that scale may have more aspects in common than kinship. But on the local scale this may be the explanation for the cluster of six burial pits and their idea of a relation to shamanism in my opinion makes sense for Mariënberg, albeit for only two of the burials and rejecting the option of wandering shamans. Grünberg (2008: 69) suggests a local or even family tradition for those instances, where sitting seems not to have been exceptional but the rule as in the case of Téviec and Hoëdic, and at the same time adding the example of Mariënberg. The remarkable age spectrum of the Téviec cemetery suggests that special causes of death (child birth, violent conflict) may have played a part: 13 of the individuals were aged 20-30 years (eight women and five men); five were very young children; while the remaining three individuals were c. 4,15 and 40 years old respectively. The spectrum of Hoëdic is in contrast 'normal', with ages ranging from newborn up to 60 years. The question thus remains, to what extent may these cemeteries be viewed as representative of a regional tradition, or should they be seen as exceptional cases? This is particularly difficult to determine given the extreme scarcity of Mesolithic burial evidence in Central and Northern France. For Mariënberg there can be no doubt of its uniqueness when compared to other Mesolithic / Swifterbant burial evidence for the Lower Rhine region and that explanations of 'family' or 'local tradition' alone does not sufficiently help our understanding of the site.

\section{Acknowledgements}

I am grateful first of all to Dr. A.D. Verlinde who gave me access to all detailed drawings of the graves and to his slides, who discussed all matters concerning the site openly with me, in spite of the fact that this paper would criticize some of his current views. Judith Grünberg drew my attention to her 2008 paper in Die Kunde. Mr. Lucas Timmerman gave me valuable personal information on the excavation and gave me the chance to study material in his possession and in the Hardenberg Museum. Judith Jansen was of great help at the Provincial Archaeological Depot Deventer, Mr. Theo Geurtsen at the National Service for the Cultural Heritage. I thank Joanne Porck for making the drawings of Figures 1, 3-6 and 11.

\section{Notes}

1. Imbosch 5, 6961 LJEerbeek, The Netherlands. Email: louwekooijmans@planet.nl.

2. No photos of sections of the Mariënberg hearths seem to have been made and these are overall rarely illustrated in publications. The Hattemerbroek hearths are similar in all aspects to those of Mariënberg ( $c f$. Lohof et al., 2011: Fig. 4.2 with Verlinde \& Newell, 2005: Fig. 2.).

3. These phases are indicated rather confusingly as 'mode IV-I' in the publication, mode IV being the oldest. We use here 'phase $1-4$ ', 1 being the oldest. The phasing is based primarily on the OxCal graph of the 38 excavation dates in Amkreutz (site catalogue, in prep).

4. On the field plan of grave 91, level 9 'possible fragments of tooth enamel' is indicated. These consisted of only one or two tiny unidentified fragments that crumbled in the field and yielded no decisive evidence.

5. The publications lack a detailed plan of the features in relation to surrounding hearths and pits, Figure 74 indicating only the 'graves'. The overall map scale of 1:400 provides insufficient resolution so I consulted the original field drawings for full details.

6. Two small samples have been studied by various specialists in an early stage of research, the other six by BIAXConsult as part of a major research grant.

7. Verlinde \& Newell, 2006: 130.

8. It should be noted that the BIAX data of Appendix 3 (2006: 268-269) have only partly been quoted in the text (grave descriptions: 125-130, and overview: 132).

9. Red sand is not dated more accurately than sometime after the Late Glacial and before Medieval times. A date around $6000 \mathrm{cal}$ BC would mean a first more or less accurate date for this phenomenon.

10.I am not certain whether the 'settlement waste from the ochre layer' is red-stained as well. If it is not, this may be explained by different reaction as a result of patination. It would be interesting to know whether settlement waste would be restricted to the upper part of the 'ochre layer'. This distinction is however only made twice. In burial pit 55 this waste (four flints) has been found "higher up the ochre layer" and in no. 92 three flakes have been found at the deposition level in the lower part, 
12 in the upper part (Verlinde \& Newell, 2006: 159 \& 163).

11. The hammerstone of pit no. 12 is indicated in the original reconstruction sketch in a position well above the ochre layer, and c. 40 $\mathrm{cm}$ above the polishers at the base.

12.I use here the data from her 2000 publication and not those from 2008, in which the 'missing data' are not mentioned. These have a considerable effect on the percentage scores. The total number of sitting graves was 74 (certain) and 35 (questionable) in 2008.

13. This high value is considerably biased by the grave gift tradition in the Téviec and Hoëdic cemeteries.

\section{References}

Amkreutz, L., in prep. Negotiating neolithisation. A long term perspective on communities in the process of neolithisation in the Lower Rhine Area (600o-250o cal BC). Ph.D. thesis, University of Leiden, Leiden.

Arts, N. \& M. Hoogland, 1987. A Mesolithic settlement area with a human cremation grave at Oirschot V, municipality of Best, the Netherlands. Helinium 27: 172-189.

Bakker, D.C.E. \& H. Rogaar, 1993. Roodzand op de Veluwe. Grondboor \& Hamer 1/2: 24-28.

Bakker, D.C.E., 1991. Roodzand in het Ginkelse Zand. Unpublished MA-thesis, Universiteit of Wageningen, Wageningen.

Deeben, J., 1995. De laatpaleolithische en mesolithische sites bij Geldrop (N.Br.). Deel 2. Archeologie 6: 3-52.

Dohrn-Ihmig, M., 1983. Das bandkeramische Gräberfeld von Aldenhoven-Niedermerz, Kreis Düren. In: G. Bauchhenss (ed.), Archäologie in den Rheinischen Lößbörden. Beiträge zur Siedlungsgeschichte im Rheinland (= Rheinische Ausgrabungen 24). Rheinland-Verlag, Köln, 47-19o.

Es, W.A. van, H. Sarfatij \& P.J. Woltering (eds.), 1988. Archaologie in Nederland. De rijkdom van het bodemarchief. Meulenhoff/ Landshoff, Amsterdam \& Amersfoort.
Gijn, A.L. van \& R. Houkes, 2001. Natuursteen. In: L.P. Louwe Kooijmans (ed.), HardinxveldGiessendam, De Bruin. Een jachtkamp uit het Laat-Mesolithicum en het begin van de Swifterbant-cultuur, 5500-4450 v. Chr. (= Rapportage Archeologische Monumentenzorg 85). Rijksdienst voor het Oudheidkundig Bodemonderzoek, Amersfoort, 193-207.

Groenendijk, H.A., 1987. Mesolithic hearth-pits in the Veenkoloniën (prov. Groningen, the Netherlands): defining a specific use of fire in the Mesolithic. Palaeohistoria 29: 85-102.

Groenendijk, H.A., 2001. Middle Mesolithic occupation on the extensive site NP3 in the peat reclamation district of Groningen, the Netherlands. In: Ph. Crombé \& P. Vermeersch (eds.), Proceedings of the XIVth Congress of the UISPP, Liège 2001, section 7 The Mesolithic (= British Archaeological Reports, International Series 1302). Archaeopress, Oxford, 19-26.

Groenendijk, H.A. \& J.L. Smit, 1990. Mesolithische Herdstellen: Erfahrungen eines Brennversuchs. Archäologischen Informationen 13: 213-220.

Grünberg, J.M., 2000. Mesolithische Bestattungen in Europa. Ein Beitrag zur vergleichende Gräberkunde (= Internationale Archäologie 40). Verlag Marie Leidorf, Rhaden.

Grünberg, J.M., 2008. Aufrecht ins Jenseits: die sitzende Haltung von Verstorbenen im Mesolithikum. Die Kunde N.F. 59: 39-89.

Hermsen, I., 2006. Mesolithische haardkuilen of houtskoolmeilers aan de Vrouwenlaan. Verslag van een noodopgraving met brandkuilen en vuursteen uit de tijd van jagers en verzamelaars in Zwolle (= Archeologische Rapporten Zwolle 39). Gemeente Zwolle, Zwolle.

Kubiak-Martens, L., L.I. Kooistra, J.J. Langer, 2008. Mesolithische teerproductie in Hattemerbroek (= BIAXiaal 387). BIAX, Zaandam.

Lohof, E., T. Hamburg \& J. Flamman, 2011. Steentijd opgespoord. Archeologisch onderzoek in het tracé van de Hanzelijn-Oude Land (= Archol Rapport 138 / ADC Rapport 2576). Archol / ADC, Leiden \& Amersfoort. 
Louwe Kooijmans, L.P. (ed.), 2001a. Hardinxveld-Giessendam, Polderweg. Een jachtkamp uit het Laat-Mesolithicum, 5500-5000 v. Chr. (= Rapportage Archeologische Monumentenzorg 83). Rijksdienst voor het Oudheidkundig Bodemonderzoek, Amersfoort.

Louwe Kooijmans, L.P. (ed.), 2001b. HardinxveldGiessendam, De Bruin. Een jachtkamp uit het Laat-Mesolithicum en het begin van de Swifterbant-cultuur, 5500-4450 v. Chr. (= Rapportage Archeologische Monumentenzorg 85). Rijksdienst voor het Oudheidkundig Bodemonderzoek, Amersfoort.

Louwe Kooijmans, L.P., 2007, Multiple choices, mortuary practices in the Low Countries during the Mesolithic and Neolithic, 9000-3000 cal BC. Berichte der RömischGermanischen Kommission 88: 449-477.

Meiklejohn, C., G. Bosset \& F. Valentin, 2010. Radiocarbon dating of Mesolithic human remains in France. Mesolithic Miscellany 21.1: 10-57.

Modderman, P.J.R., 1970. Linearbandkeramik aus Elsloo und Stein (= Analecta Praehistorica Leidensia 3). Leiden University Press, Leiden.

Niekus, M.J.L.Th., 2006. A geographically referenced ${ }^{14} \mathrm{C}$ database for the Mesolithic and the early phase of the Swifterbant culture in the northern Netherlands. Palaeohistoria 47/48 (2005/2006): 41-99.

Peeters, H \& M. Niekus, 2005. Het mesolithicum van Noord-Nederland. In: J. Deeben et al. (eds.), De steentijd van Nederland (= Archeologie 11/12). Stichting Archeologie, Zutphen, 201-234.

Raemaekers, D.C.M., H.M. Molthof \& L. Smits, 2007. The textbook 'dealing with death' from the Neolithic Swifterbant culture (5000-3400 $\mathrm{BC})$, the Netherlands. Berichte der RömischGermanischen Kommission 88: 529-550.
Smits, L. \& J. van der Plicht, 2009. Mesolithic and Neolithic human remains in the Netherlands: physical anthropological and stable isotope investigations. Journal of Archaeology in the Low Countries 1.1: 55-85. (http://dpc.uba.uva.nl/jalc/o1/nro1/ao4).

Verlinde, A.D., 1974. A Mesolithic Settlement with Cremation at Dalfsen. Berichten van de Rijksdienst voor het Oudheidkundig Bodemonderzoek 24: 113-117.

Verlinde A.D. 1979. Archeologische kroniek van Overijssel over 1977/1978. Overijsselse Historische Bijdragen 94: 99-117.

Verlinde, A.D., 1982. Archeologische kroniek van Overijssel over 1980/1981. Overijsselse Historische Bijdragen 97: 167-208.

Verlinde, A.D., 2005. Mesolithic along the Overijssel Vecht. A camp site and burials at Mariënberg. In: L.P. Louwe Kooijmans et al. (eds.), The prehistory of the Netherlands. Vol. I. Amsterdam University Press, Amsterdam, 179-182.

Verlinde, A.D. \& R.R. Newell, 2005. Zes laatmesolithische 'sitting graves' tussen honderden haardplekken uit 7600-5000 voor Chr. te Mariënberg (Ov.). Westerheem 54: 1-13.

Verlinde, A.D. \& R.R. Newell, 2006. A multicomponent complex of Mesolithic settlements with Late Mesolithic grave pits at Mariënberg in Overijssel. In: B.J. Groenewoudt et al. (eds.), Het zandeilandenrijk van Overijssel $(=$ Nederlandse Archeologische Rapporten 22). Rijksdienst voor het Oudheidkundig Bodemonderzoek, Amersfoort, 83-270.

Zijl, W., M.J.L.Th. Niekus, P.H.J.I. Ploegaert \& J.M. Moree (with contributions by S.B.C. Bloo, O. Brinkkemper, A.L. van Gijn, L. Smits, A. Verbaas \& J. Zeiler), 2011. Rotterdam Beverwaard Tramremise. De opgraving van de top van een donk met sporen uit het Mesolithicum en Neolithicum (vindplaats 13-83) (= BOORrapporten 439). Gemeente Rotterdam, Rotterdam. 